\title{
Analysis of Aquifer Tests Conducted in Boreholes USW WT-10, UE-25 WT\#12, and USW SD-7, 1995-96, Yucca Mountain, Nevada
}

by Grady M. O'Brien

\section{U.S. GEOLOGICAL SURVEY}

Water-Resources Investigations Report 96-4293

Prepared in cooperation with the

NEVADA OPERATIONS OFFICE,

U.S. DEPARTMENT OF ENERGY, under

Interagency Agreement DE-Al08-92NV10874

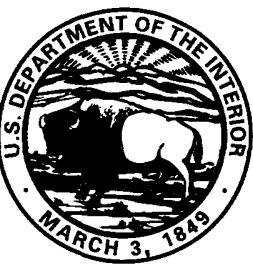




\title{
U.S. DEPARTMENT OF THE INTERIOR BRUCE BABBITT, Secretary
}

\author{
U.S. GEOLOGICAL SURVEY
}

Gordon P. Eaton, Director

The use of firm, trade, and brand names in this report is for identification purposes only and does not constitute endorsement by the U.S. Geological Survey.

For additional information write to:

Chief, Earth Science Investigations Program Yucca Mountain Project Branch

U.S. Geological Survey

Box 25046, Mail Stop 421

Denver Federal Center

Denver, CO 80225-0046
Copies of this report can be purchased from:

U.S. Geological Survey

Branch of Information Services

Box 25286

Denver, CO 80225-0286 


\section{CONTENTS}

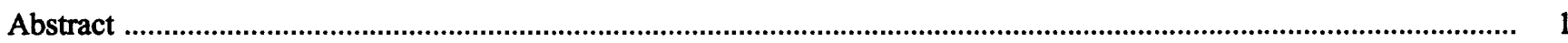

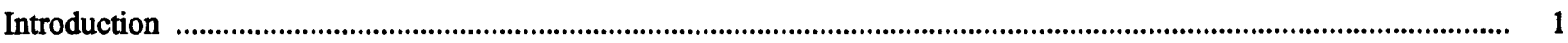

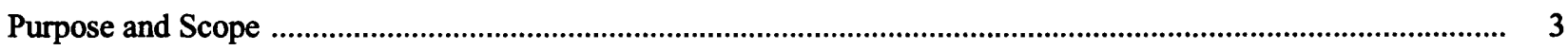

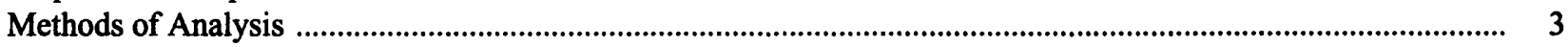

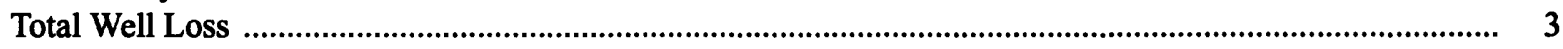

Borehole Storage ....................................................................................................................................... 4

Straight-Line Method ............................................................................................................................. 4

Specific Capacity ............................................................................................................................................. 5

American Society for Testing Materials Method …..................................................................................... 5

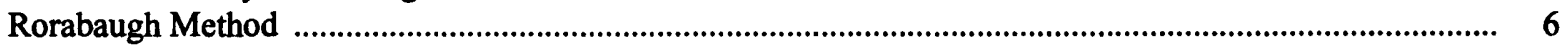

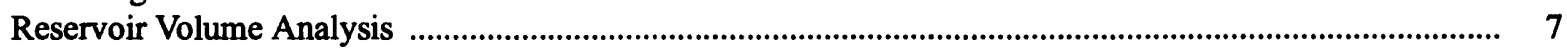

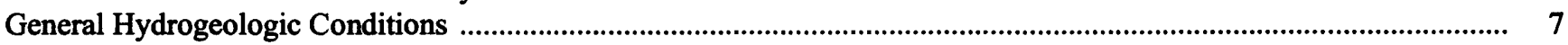

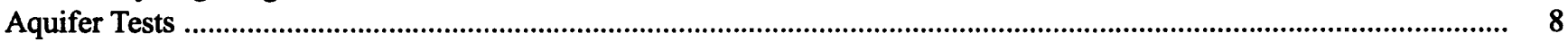

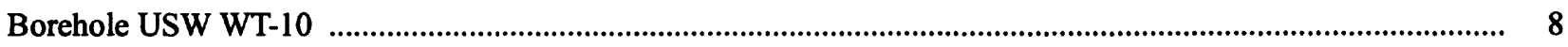

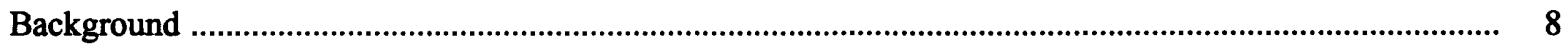

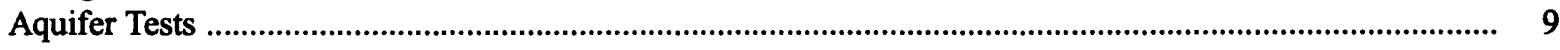

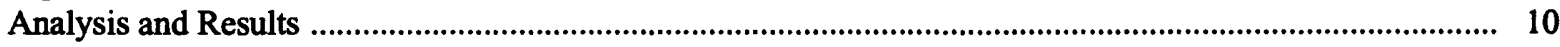

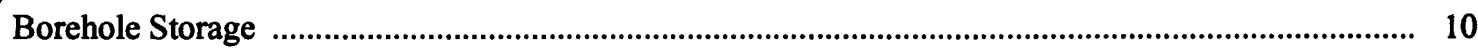

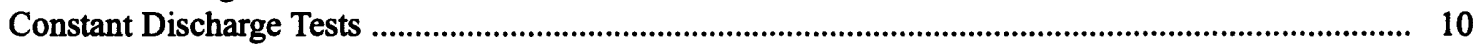

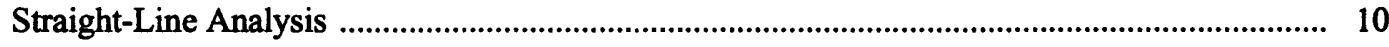

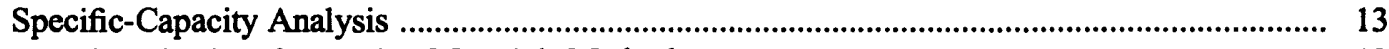

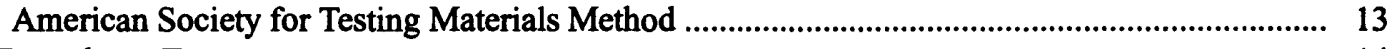

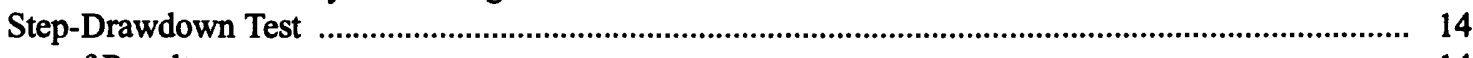

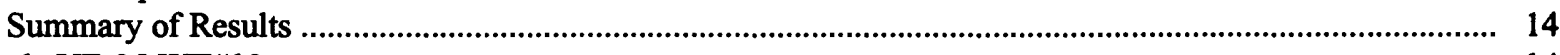

Borehole UE-25 WT\#12 ................................................................................................................................... 14

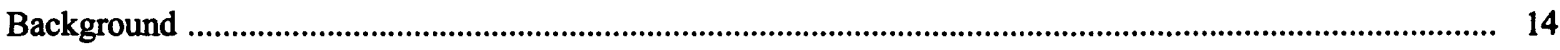

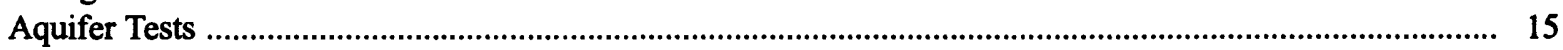

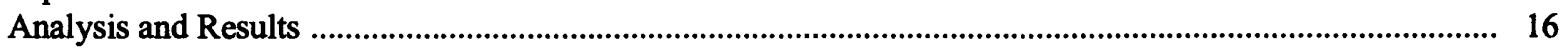

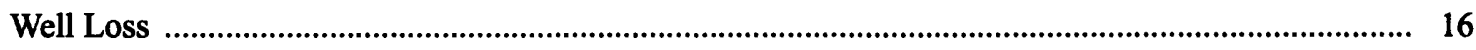

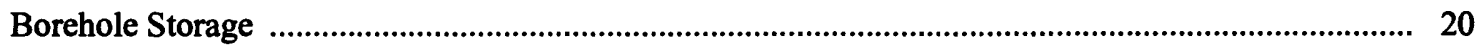

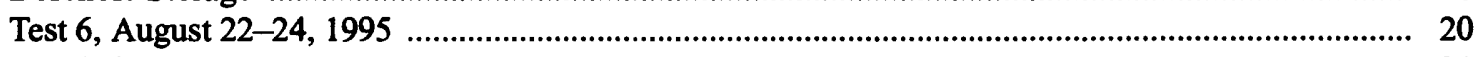

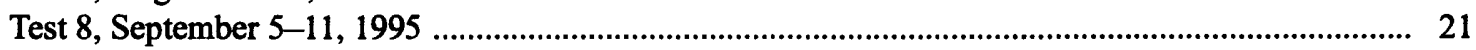

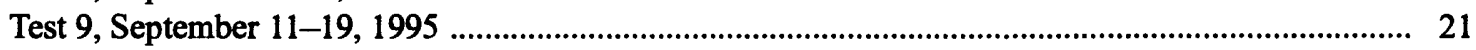

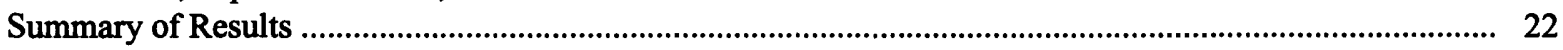

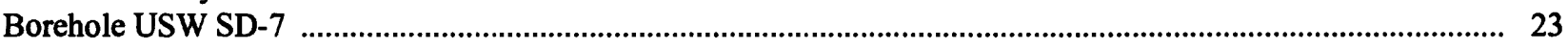

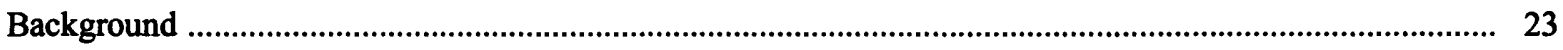

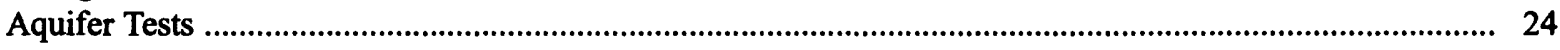

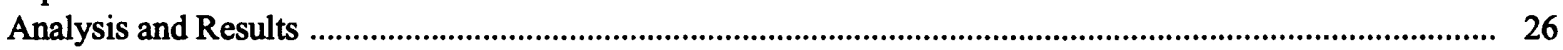

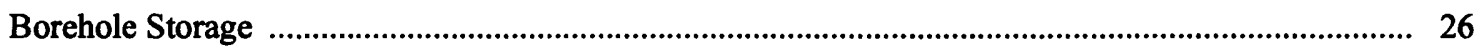

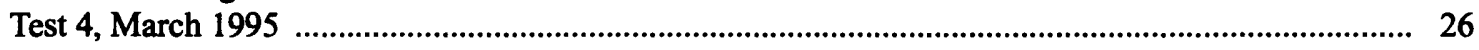

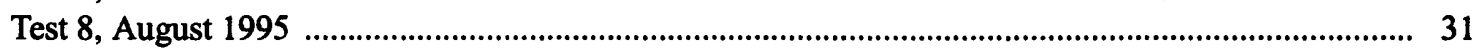

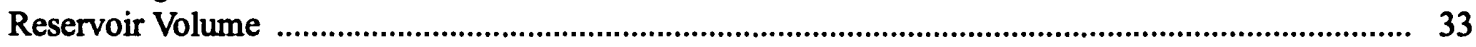

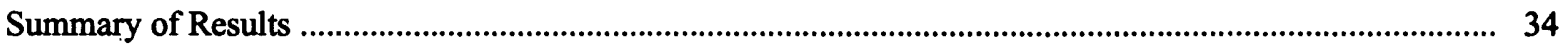

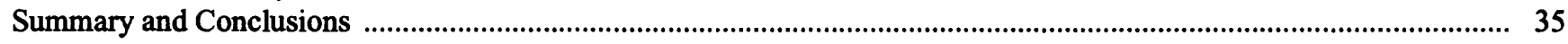

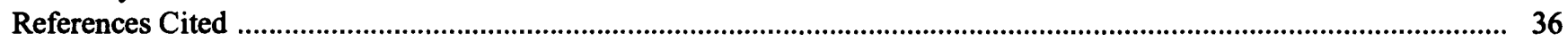




\section{FIGURES}

1. Map showing location of selected deep boreholes in the vicinity of Yucca Mountain

2-17. Graphs showing:

2. Aquifer-test analysis by straight-line analytical solution for drawdown data during test 2 , January 11, 1996, in borehole USW WT-10

3. Aquifer-test analysis by straight-line analytical solution for drawdown data during test 3 , January 16, 1996, in borehole USW WT-10...

4. Drawdown and discharge as a function of time during step-drawdown test 4, January 17,1996 , in borehole USW WT-10

5. Aquifer-test analysis by straight-line analytical solution for drawdown data during test 5 , January 18, 1996, in borehole USW WT-10

6. Aquifer-test analysis by straight-line analytical solution for drawdown data during test 6 , August 22-24, 1995, in borehole UE-25 WT\#12

7. Aquifer-test analysis by straight-line analytical solution for drawdown data during test 8 , September 5-11, 1995, in borehole UE-25 WT\#12.

8. Aquifer-test analysis by straight-line analytical solution for drawdown data during test 9 , September 11-15, 1995, in borehole UE-25 WT\#12.

9. Drawdown and discharge fluctuations as a function of time during aquifer test 8 ,

September 5-11, 1995, in borehole UE-25 WT\#12.

10. Recovery of residual drawdown as a function of time for aquifer test 6 , August 24,1995 , in borehole UE-25 WT\#12.

11. Recovery of residual drawdown as a function of time for aquifer test 9, September $15-19,1995$, in borehole UE-25 WT\#12

12. Measured drawdown and digitally filtered drawdown as a function of time during aquifer test 4 , March 20-21, 1995, in borehole USW SD-7.

13. Measured drawdown and digitally filtered drawdown as a function of time during aquifer test 8 , August 15-18, 1995, in borehole USW SD-7.

14. Recovery of residual drawdown as a function of time for aquifer test 4, March 21-27, 1995, in borehole USW SD-7.

15. Recovery of residual drawdown as a function of time for aquifer test 8 , August $18-24,1995$, in borehole USW SD-7.

16. Digitally filtered drawdown data as a function of time and determination of aquifer characteristics used in the Rorabaugh method and reservoir-volume analysis for aquifer test 4, March 20-21, 1995, in borehole USW SD-7

17. Aquifer-test analysis by straight-line analytical solution using digitally filtered drawdown data for test 4, March 20-21, 1995, in borehole USW SD-7

18. Diagrammatic section showing idealized conceptual model of perched-water system intersected by borehole USW SD-7

19-21. Graphs showing:

19. Digitally filtered drawdown data as a function of time and determination of aquifer characteristics used in the Rorabaugh method and reservoir-volume analysis for test 8, August 11-15, 1995, in borehole USW SD-7.

20. Steel-tape depth-to-water measurements in borehole USW SD-7, between March 13 and August 24, 1995

21. Aquifer-test analysis by straight-line analytical solution using digitally filtered drawdown data for test 8, August 15-18, 1995, in borehole USW SD-7.... 


\section{TABLES}

1-9. Summary of:

1. Borehole USW WT-10 completion

2. Borehole USW WT-10 aquifer testing, January 9-22, 1996 .............................................................. 9

3. Transmissivity determined with straight-line and ASTM methods for borehole USW WT-10 ................... 13

4. Specific capacity obtained from aquifer tests $2,3,4$, and 5 in borehole USW WT-10.............................. 13

5. Borehole UE-25 WT\#12 completion ...................................................................................... 15

6. Aquifer tests in borehole UE-25 WT\#12 for tests 3 through 9, August 19-September 15, $1995 \ldots \ldots \ldots \ldots \ldots \ldots . . .16$

7. Specific-capacity values determined for aquifer tests 6,8 , and 9 in borehole UE-25 WT\#12 .................... 20

8. Transmissivity values determined for aquifer tests 6,8 , and 9 in borehole UE-25 WT\#12 ...................... 20

9. Borehole USW SD-7 configuration during the March and August 1995 aquifer tests ................................. 23

10. Depth-to-water measurements made with calibrated steel tapes, in borehole USW SD-7, between March 13 and August 24, 1995................................................................................................................ 25

11. Reservoir-volume estimates for the March and August 1995 aquifer testing in borehole USW SD-7 ................. 34

12. Summary of transmissivity estimates from aquifer tests 4 and 8 in borehole USW SD-7 7................................ 34

CONVERSION FACTORS AND VERTICAL DATUM

\begin{tabular}{rll}
\hline Multiply & By & To obtaln \\
\hline meter $(\mathrm{m})$ & 3.281 & foot \\
kilometer $(\mathrm{km})$ & 0.6214 & mile \\
square kilometer $\left(\mathrm{km}^{2}\right)$ & 0.3861 & square mile \\
liter $(\mathrm{L})$ & 0.2642 & gallon \\
liter per second $(\mathrm{L} / \mathrm{s})$ & 15.85 & gallon per minute \\
meter squared per day $\left(\mathrm{m}^{2} /\right.$ day) & 10.76 & foot squared per day \\
millimeter $(\mathrm{mm})$ & 0.03937 & inch \\
\hline
\end{tabular}

Temperature in degrees Celsius $\left({ }^{\circ} \mathrm{C}\right)$ may be converted to degrees Fahrenheit $\left({ }^{\circ} \mathrm{F}\right)$ as follows:

$$
{ }^{\circ} \mathrm{F}=\left(1.8 \times{ }^{\circ} \mathrm{C}\right)+32
$$

Sea level: In this report, "sea level" refers to the National Geodetic Vertical Datum of 1929 (NGVD of 1929) - a geodetic datum derived from a general adjustment of the first-order level nets of both the United States and Canada, formerly called Sea Level Datum of 1929. 


\section{Analysis of Aquifer Tests Conducted in Boreholes USW WT-10, UE-25 WT\#12, and USW SD-7, 1995-96, Yucca Mountain, Nevada}

\author{
By Grady M. O'Brien
}

\section{Abstract}

Single-borehole aquifer tests were conducted in three boreholes in the Yucca Mountain area between March 1995 and January 1996 to obtain estimates of borehole specific capacity and aquifer transmissivity. Analysis of aquifer testing in borehole USW SD-7 also resulted in an estimate of reservoir volume. Aquifer-test data were analyzed with the Cooper and Jacob straight-line method, two modified Theis nonequilibrium equation solutions, and a modified reservoir-limit solution.

The highest estimates of transmissivity were in borehole USW WT-10, completed in the Topopah Spring Tuff. Mean transmissivity, based on the results of three drawdown tests, was 1,600 meters squared per day. Mean specific capacity in borehole USW WT-10 after 5 hours of pumping was 1,100 meters squared per day, and was estimated to be 740 meters squared per day after 24 hours of pumping. Aquifer testing in borehole UE-25 WT\#12 appeared to be significantly affected by well losses. A mean transmissivity of 7 meters squared per day was obtained on the basis of analysis of three drawdown tests in borehole UE-25 WT\#12. Mean specific capacity in borehole UE-25 WT\#12, after 24 hours of pumping, was 7 meters squared per day. Borehole UE-25 WT\#12 seemed to be producing water from fractures that could provide only a limited amount of water to the borehole.

A perched-water body was tested during March and August 1995 in borehole USW SD-7. The top of the perched-water reservoir was approximately 150 meters above the regional water table. A mean transmissivity of 6 meters squared per day was estimated on the basis of two drawdown tests. Pre-pumping reservoir volume was estimated to be 96,000 liters in borehole USW SD-7.

The aquifer testing in boreholes USW WT-10 and UE-25 WT\#12 was the first attempt at obtaining transmissivity estimates at these sites since the boreholes were completed in August 1983. Borehole USW SD-7 provided the opportunity to test a perched-water body and to obtain estimates of transmissivity and reservoir volume.

\section{INTRODUCTION}

The U.S. Geological Survey is conducting hydrologic and geologic investigations of Yucca Mountain, Nevada, to determine its suitability to store high-level nuclear waste in an underground, mined geologic repository. The site area, approximately $150 \mathrm{~km}^{2}$, is about $150 \mathrm{~km}$ northwest of Las Vegas in southern Nevada. This investigation was conducted in cooperation with the U.S. Department of Energy under Interagency Agreement DE-AI08-92NV10874 as part of the Yucca Mountain Site Characterization Project. All data analyzed and interpreted in this report were collected as required by the U.S. Geological Survey, Yucca Mountain Project Branch Quality-Assurance Program, and are considered qualified. Aquifer tests included in this report were conducted in boreholes USW WT-10, UE-25 WT\#12, and USW SD-7 (fig. 1). In the Yucca Mountain area, the regional water table is in air-fall and ash-flow tuffs of Tertiary age. At the time of aquifer testing in borehole USW SD-7, the 


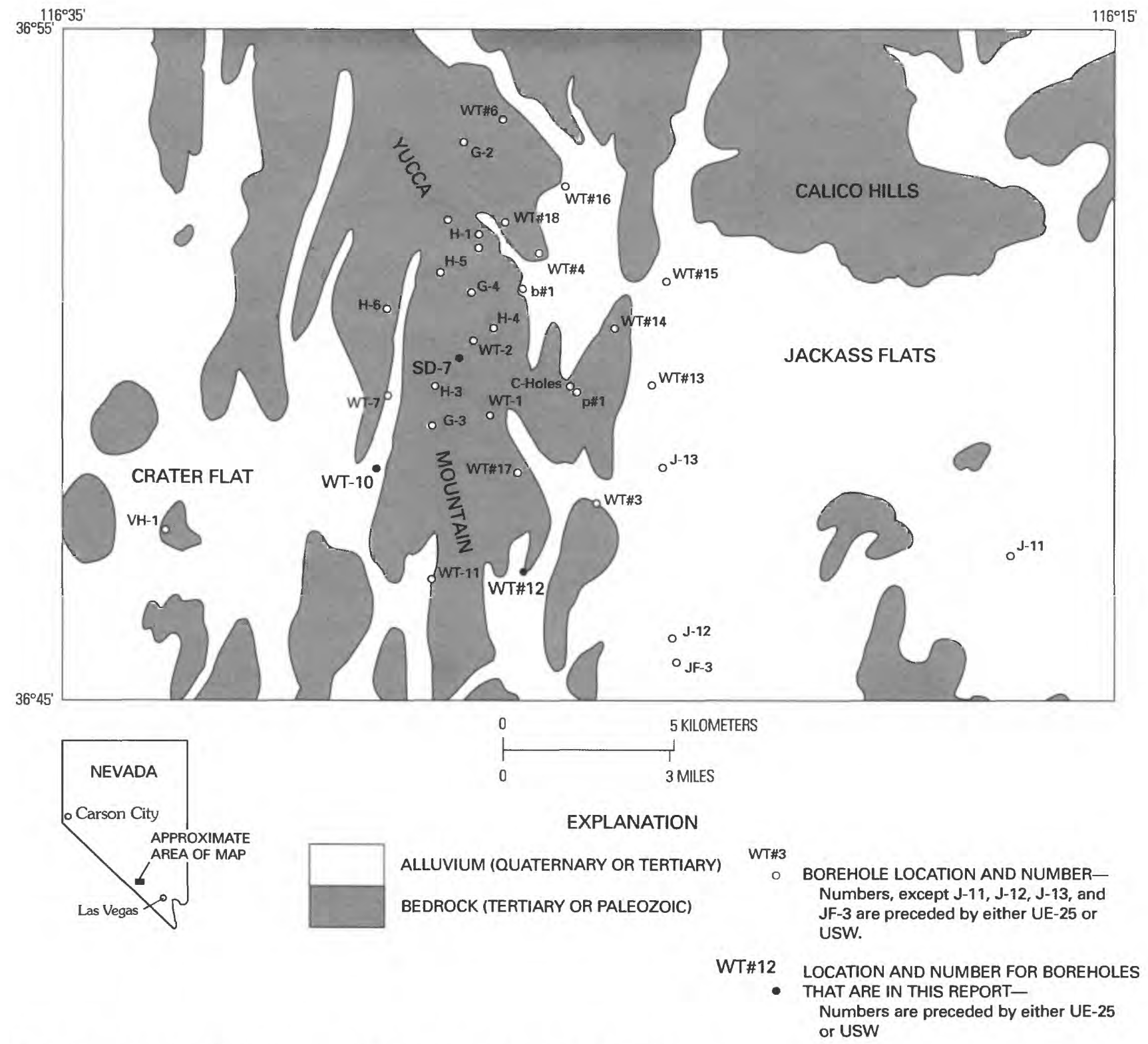

Figure 1. Location of selected deep boreholes in the vicinity of Yucca Mountain. 
water level was approximately $150 \mathrm{~m}$ above the regional water table and, therefore, considered to be perched.

Water-level and related data obtained during aquifer testing of the boreholes and the subsequent analysis and interpretation of these data are included in this report. Estimates of borehole specific capacity and aquifer transmissivity were determined for each borehole. The Cooper and Jacob (1946) straight-line analytical method determined transmissivity in the three boreholes. An American Society for Testing Materials (ASTM) method (1993) was used to estimate transmissivity on the basis of specific capacity in boreholes USW WT-10 and UE-25 WT\#12. Rorabaugh's (1956) method was also used to estimate transmissivity in borehole USW SD-7. Recovery data were not suitable for determining transmissivity in the three boreholes. An estimate of the volume of the perched-water body in borehole USW SD-7 was determined on the basis of a modified reservoir-limit equation (Earlougher, 1977).

Water levels were monitored in the boreholes with calibrated pressure transducers, controlled by electronic data loggers. Prior to and after pumping, water levels in the boreholes were manually measured with calibrated steel tapes. Each borehole was pumped by using a progressive cavity pump with a hydraulic or mechanical drive. Pump discharge was measured with calibrated flow meters and by manual volumetric measurements.

\section{Purpose and Scope}

This report presents descriptions, analyses, and interpretations of the single-hole aquifer tests conducted in boreholes USW WT-10, UE-25 WT\#12, and USW SD-7. These tests were conducted between March 1995 and January 1996 to obtain borehole specific-capacity and aquifer transmissivity estimates. In addition, aquifer tests in borehole USW SD-7 were analyzed to estimate the volume of the perched-water reservoir.

\section{Methods of Analysis}

The methods used to determine aquifer transmissivity in boreholes USW WT-10, UE-25 WT\#12, and USW SD-7 were limited to solutions applicable to single-borehole aquifer tests. The Cooper and Jacob (1946) straight-line method, Rorabaugh (1956) method, and an ASTM (1993) method were used to analyze drawdown data to estimate transmissivity. Time/distance methods could not be used because observation holes were not located within the area affected by pumping.

Single-borehole tests in water-table aquifers cannot generally provide reliable estimates of aquifer storage. Straight-line solutions require that specific conditions be met to produce reliable specific-yield estimates. For example, the radius of the borehole must be accurately known (Lohman, 1979, p. 24). Because data are not available to determine accurately effective radius of the three boreholes, specific$j$ icid estimates would be unreliable and are not reported.

Analysis of recovery data generally is preferable over drawdown data in single-hole aquifer tests because errors introduced during pumping are not present. Recovery data can be used to validate the drawdown data that may be affected by well losses (Driscoll, 1986, p. 554). Other benefits of recovery analysis are that the pump is shut off so the discharge rate is precisely known and that discharge fluctuations do not affect the drawdown. Recovery data for the three boreholes tested, however, were interpreted to be unreliable, and transmissivity estimates that are based on recovery data are not provided. Further discussion of recovery data is provided in the "Analysis and Results" sections for the individual boreholes.

\section{Total Well Loss}

Transmissivity values determined from a pumped borehole are often subject to error because of total well loss. "Total well loss" is defined as the difference between the observed pumped-well drawdown and the theoretical aquifer drawdown at the well face (Kawecki, 1995). Drawdown can be affected by unavoidable friction losses in the aquifer as water moves toward the borehole (Driscoll, 1986, p. 584). Head loss can also be due to improper selection of screen and gravel pack during well design. The three boreholes presented in this report were tested under open-hole conditions, with no casing, screen, or gravel pack. Substantial head losses can also be sustained as water flows through the zone disturbed during drilling around the borehole (Driscoll, 1986, p. 584). 
The magnitude of head losses in the pumped well are often estimated by analysis of step-drawdown tests. Many methods have been proposed to analyze step-drawdown tests, and there is considerable debate as to the validity of the methods (Driscoll, 1986; Kawecki, 1995). Most methods are designed for use in confined aquifers and may provide unreliable results when applied to water-table aquifers. A step-drawdown test was conducted in borehole USW WT-10, and the data were analyzed in an attempt to estimate borehole efficiency. Attempts at conducting step-drawdown tests in boreholes UE-25 WT\#12 and USW SD-7 were unsuccessful, probably because of unfavorable aquifer and borehole conditions. Head loss is inherent in most aquifer tests and most likely affected all the aquifer tests analyzed in this report. Errors in the estimated transmissivities because of head loss were probably significant only in borehole UE-25 WT\#12.

\section{Borehole Storage}

Early time aquifer-test data can be affected by borehole storage and may not fit Jacob's modification of the nonequilibrium theory (Schafer, 1978). Analysis of the early-time drawdown data that is affected by borehole storage would result in erroneous transmissivity estimates. When pumping is started, the water in the borehole is removed first. As the water level in the borehole drops, water begins to enter the borehole from the surrounding aquifer. As pumping continues, a greater percentage of the borehole yield comes from the aquifer (Driscoll, 1986, p. 232). A method for determining when borehole storage is negligible was developed by Schafer (1978) and is used in this report to ensure that erroneous drawdown data are not analyzed. Advantages of the method suggested by Schafer (1978) are that well efficiency and transmissivity do not need to be known. The time at which borehole storage is negligible is given by:

$$
t_{c}=\frac{0.017\left(d_{w}^{2}-d_{p}^{2}\right)}{Q / s},
$$

where:

$$
\begin{aligned}
t_{c}= & \text { time when borehole storage effect becomes } \\
& \text { negligible, in minutes; }
\end{aligned}
$$

$$
\begin{gathered}
d_{p}=\text { outside diameter of the pump column pipe, } \\
\text { in mm; } \\
Q / s=\begin{array}{c}
\text { specific capacity of the borehole at time } t_{c}, \text { in } \\
\left.\mathrm{m}^{3} / \text { day } / \mathrm{m} \text { (Schafer, } 1978\right) ;
\end{array}
\end{gathered}
$$

\section{Straight-Line Method}

Cooper and Jacob (1946) developed a straightline graphical method, which does not require typecurve matching or observation wells to determine the transmissivity in a pumped borehole. All drawdown tests analyzed in this report were analyzed by using the Cooper and Jacob method. The equation for the straight-line method is:

$$
T=\frac{15.8 Q}{\Delta s}
$$

$$
\begin{aligned}
\text { where } & \\
T & =\text { transmissivity }\left(\mathrm{m}^{2} / \text { day }\right) \\
Q & =\text { discharge }(\mathrm{L} / \mathrm{s}) ; \text { and } \\
\Delta s & =\text { change in drawdown over one log cycle of } \\
& \text { time }(\mathrm{m}) .
\end{aligned}
$$

Transmissivity estimates for the individual boreholes are presented in the "Analysis and Results" sections.

Use of the Cooper and Jacob straight-line method is applicable only at times when $u$, as defined by equation 3 , is less than or equal to about 0.01 (Cooper and Jacob, 1946; Lohman, 1979, p. 22). Consistent units must be used when solving equation 3.

$$
u=\frac{r^{2} S_{y}}{4 T t},
$$

where

$$
\begin{aligned}
r= & \text { distance from discharging well to point of } \\
& \text { observation of drawdown }(\mathrm{L}) ; \\
S_{y}= & \text { specific yield (dimensionless); } \\
T= & \text { transmissivity }\left(\mathrm{L}^{2} / \mathrm{t}\right) ; \\
t= & \text { time since pumping began }(\mathrm{t}) ; \\
(\mathrm{L})= & \text { consistent unit of length; and } \\
(\mathrm{t})= & \text { consistent unit of time. }
\end{aligned}
$$

The pumping time in an unconfined aquifer must be long enough to allow reasonably complete drainage of water from material within the part of the cone of 
depression being observed (Lohman, 1979). Data points will fall on a straight line only after the time, $t$, is sufficiently long to satisfy the criteria of $u<0.01$. Unconfined aquifers require longer pumping time to reduce the value of $u$ because specific yield is generally several orders of magnitude larger than the storage coefficient in confined aquifers (Lohman, 1979). All tests presented were conducted in fractured rock, which typically has lower specific yield than unconsolidated materials under water-table conditions. Specific yield was assumed to be 0.01 for purposes of determining $u$. Values of $u$ were calculated to determine when sufficient time had elapsed to allow application of the straight-line method.

Straight-line solutions can be used to estimate specific yield if the radius of the borehole is known (Cooper and Jacob, 1946; Lohman, 1963; Lohman, 1979). These methods should not be used when the radius of the borehole is uncertain (Lohman, 1979). The solution to determine specific yield, with consistent units, is:

$$
S_{y}=\frac{2.25 T t / r_{w}^{2}}{\log _{10}{ }^{-1}\left[\left(s_{w} / Q\right) /\left(\Delta s_{w} / Q\right)\right]}
$$

where:

$S_{y}=$ specific yield (dimensionless);

$T=$ transmissivity $\left(\mathrm{L}^{2} / \mathrm{t}\right)$;

$t=$ time since pumping began $(\mathrm{t})$;

$r_{w}=$ borehole radius $(\mathrm{L})$;

$s_{w}=$ drawdown in the borehole $(\mathrm{L})$;

$Q$ = pump discharge $\left(\mathrm{L}^{3 / \mathrm{t}}\right)$

(Lohman, 1979, p. 24);

(L) = consistent unit of length; and

(t) = consistent unit of time.

Caliper logs from USW WT-10 indicate that the borehole size below the water table is highly irregular and typically much larger than the drill-bit diameter. Therefore, specific yield was not determined for borehole USW WT- 10 because of the uncertainty in the radius of the hole. Caliper logs from UE-25 WT\#12 indicate that the borehole is relatively uniform in diameter and slightly larger than the drill-bit diameter. Specific-yield estimates in borehole UE-25 WT\#12, from three tests, were 0.03, 0.008, and $5 \times 10^{-5}$. Analysis of two tests in borehole USW SD-7 resulted in specific-yield estimates of 0.3 and $2 \times 10^{-4}$. These specific-yield estimates are highly variable and questionable given the hydrologic conditions. The assumptions required for proper application of the solution probably are not met, which caused the results to be unreliable. A reasonable specific yield for an unconfined, fractured-rock aquifer of 0.01 (Freeze and Cherry, 1979) was assumed for all boreholes when required for the analysis.

\section{Speclfic Capaclty}

Specific capacity of a borehole is its yield per unit of drawdown after a given time has elapsed, usually 24 hours (Driscoll, 1986, p. 207). The specific capacity of a borehole will normally decrease with increasing pumping time. Within the same borehole, increases in discharge rate will also result in lower specific-capacity values. Dividing the yield, or discharge, from the borehole by the drawdown, when both are measured at the same time, is the specific capacity. Specific capacity after 24 hours is determined and presented in the "Analysis and Results" sections for the individual boreholes.

\section{American Society for Testing Materiais Method}

An ASTM method (1993) was used to calculate transmissivity on the basis of specific-capacity values for boreholes USW WT-10 and UE-25 WT\#12. Because of the short pumping periods in borehole USW WT-10, the ASTM method was used to obtain transmissivity estimates that did not rely on the slope of the drawdown curve. Transmissivity estimates obtained from the ASTM method are compared to estimates that are based on the straight-line method. Boundary effects during the early-time data at borehole USW SD-7 make it impractical to use the ASTM method.

The ASTM method is based on the modified Theis nonequilibrium equation (Cooper and Jacob, 1946), which is solved in an iterative process with an initial transmissivity estimate. The variable of integration, $u$ (eq. 3 ), was solved with an initial estimate of transmissivity $\left(T^{\prime}\right)$ and an estimated specific yield $(0.01)$. The well function, $\mathrm{W}(u)$, was solved by using the two-term approximation. Transmissivity is the product of the specific capacity $(\mathrm{Q} / \mathrm{s})$ and the well function divided by $4 \pi$. This calculation was repeated until the transmissivity $\left(\mathrm{T}^{\prime}\right)$ 
value used in the calculation of $u$ was within 10 percent of the final transmissivity $(T)$ estimate. The modified Theis nonequilibrium equation, with consistent units, is as follows:

$$
T=\frac{Q W(u)}{4 \pi s}
$$

where:

$$
\begin{aligned}
T & =\text { transmissivity }\left(\mathrm{L}^{2} / \mathrm{t}\right) ; \\
Q / s & =\text { specific capacity }\left[\left(\mathrm{L}^{3} / \mathrm{t}\right) / \mathrm{L}\right] \\
W(u) & =\text { well function of } u=[-0.577216-\ln (u)] \\
& \quad \text { (dimensionless); } \\
\mathrm{u}= & \mathrm{r}^{2} \mathrm{~S}_{\mathrm{y}} / 4 \mathrm{~T}^{\prime} \mathrm{t} \text { (dimensionless); } \\
r= & \text { borehole radius }(\mathrm{L}) ; \\
S_{y}= & \text { specific yield (dimensionless); } \\
T= & \text { initial transmissivity estimate }\left(\mathrm{L}^{2} / \mathrm{t}\right) ; \\
t & =\text { elapsed time of pumping }(\mathrm{t}) ; \\
(\mathrm{L}) & =\text { consistent unit of length; and } \\
(\mathrm{t}) & =\text { consistent unit of time. }
\end{aligned}
$$

Cooper and Jacob (1946) realized that when $u$ is sufficiently small, the well function of $u$ can be approximated by $-0.577216-\ln (u)$ without significant error.

The modified Theis nonequilibrium solution is intended for use in confined aquifers, but when used under water-table conditions, errors should be small if the drawdown is 10 percent or less of the original saturated thickness (American Society for Testing Materials, 1993). Drawdown was less than 1 percent of the saturated thickness in borehole USW WT-10, so the error in the solution due to unconfined conditions is not considered significant. The boreholes presented in this report partially penetrate the aquifers, so the transmissivity estimates are valid only for the saturated part of the aquifer penetrated by the borehole.

\section{Rorabaugh Method}

An alternative method to the straight-line analysis was desired to obtain transmissivity estimates in borehole USW SD-7. Rorabaugh (1956) modified the Theis nonequilibrium equation so that it was expressed in terms of the distance between a real well and an image well. The image well is used to simulate the influence of a natural boundary. The solution was slightly modified here to be appropriate to the hydraulic situation in borehole USW SD-7.

Rorabaugh's equation 8 (Rorabaugh, 1956, p. 121) is rewritten in terms of the natural logarithm and modified to neglect the relatively small radius of the borehole in the distance term of the logarithm value. The modified equation used for analysis is presented as equation 6 .

$$
T=\frac{Q}{2 \pi s_{w}} \frac{\ln \left(2 R_{e}\right)}{r_{w}},
$$

where:

$$
\begin{aligned}
T= & \text { transmissivity }\left(\mathrm{L}^{2} / \mathrm{t}\right) ; \\
Q= & \text { pump discharge }\left(\mathrm{L}^{3} / \mathrm{t}\right) ; \\
R_{e}= & \text { distance from the borehole to the reservoir } \\
& \quad \text { boundary }(\mathrm{L}) ; \\
s_{w}= & \text { drawdown as determined by the y-intercept } \\
& \quad \text { of the straight line through the drawdown } \\
& \quad \text { curve }(\mathrm{L}) ; \\
r_{w}= & \text { borehole radius }(\mathrm{L}) ; \\
(\mathrm{L})= & \text { consistent unit of length; and } \\
(\mathrm{t})= & \text { consistent unit of time. }
\end{aligned}
$$

This method assumes that the aquifer is of infinite extent, under confined conditions, and that pumping has continued long enough to establish steady-flow conditions (Rorabaugh, 1956). To minimize potential errors due to violation of the equation assumptions, the solution is theoretically solved when the aquifer is responding as if it were infinite, confined, and under steady-flow conditions. The water level in the borehole rose above the top of the producing interval in borehole USW SD-7, indicating that the system was acting as if it were confined. During early pumping time, confined conditions probably existed in the reservoir and sufficiently satisfy the assumption that drawdown in the borehole causes a nearly instantaneous head drop at the boundary of the reservoir. The amount of drawdown in the borehole required to produce a head drop at the boundary is defined as $\mathrm{s}_{\mathrm{w}}$. The straight line that defines the drawdown curve on a linear time plot is extended to zero time and gives the theoretical instantaneous drawdown as the $y$-intercept $\left(s_{w}\right)$. The solution and conceptual model of the flow system is discussed further in the "Analysis and Results" section for borehole USW SD-7. 


\section{Reservoir Volume Analysis}

Under normal hydrologic testing conditions, the aquifer being tested is assumed to be infinite in areal extent. Aquifer testing at USW SD-7 was unique in that the reservoir was perched and of finite extent. The size of the perched-water reservoir has potentially important implications for the performance of the potential repository and conceptual models of the hydrologic system at Yucca Mountain.

The petroleum industry is often interested in the size of petroleum reservoirs, and reservoir-limit tests are conducted in an attempt to determine the size of the oil reserve. A reservoir-limit analysis method presented by Earlougher (1977, p. 29) was modified for use under water-table conditions found in borehole USW SD-7. The lumped drainage term, $\mathrm{S}_{\mathrm{y}} \mathrm{A}$, is the water-filled cross-sectional area in the reservoir, and it is solved for with the slope of the linear drawdown plots. The solution, which requires use of consistent units, is:

$$
S_{y} A=\frac{q}{\Delta s / \Delta t}
$$

where:

$S_{y} A=$ drainage volume term $\left(\mathrm{L}^{2}\right) ;$

$q$ = pump discharge rate $\left(\mathrm{L}^{3} / \mathrm{t}\right) ;$

$\Delta s / \Delta t=$ slope of linear drawdown plot (change in drawdown per change in time) $(\mathrm{L} / \mathrm{t})$, (Edwin Weeks, U.S. Geological Survey, oral commun., 1996).

(L) = consistent unit of length; and

(t) = consistent unit of time.

To check the validity of the $\mathrm{S}_{\mathrm{y}} \mathrm{A}$ term, equation 8 is used to calculate the theoretical discharged volume based on the known residual drawdown. The known discharged volume should compare reasonably well to the theoretical volume if the solution is appropriate.

$$
Q=S_{y} A \bullet \Delta s_{r}
$$

where:

$$
\begin{gathered}
Q=\begin{array}{c}
\text { theoretical volume of water removed from } \\
\text { the reservoir }\left(\mathrm{L}^{3}\right) ;
\end{array} \\
S_{y} A=\begin{array}{c}
\text { drainage volume term }\left(\mathrm{L}^{2}\right) \text { [determined from } \\
\text { equation } 7] ;
\end{array}
\end{gathered}
$$

$\Delta s_{r}=$ measured residual drawdown due to pumping (L).

(L) = consistent unit of length; and

(t) = consistent unit of time.

Once the validity of the $\mathrm{S}_{\mathrm{y}} \mathrm{A}$ term is established based on testing results, the total volume of the reservoir drained by borehole USW SD-7 can be estimated with equation 8. The $\Delta \mathrm{s}_{\mathrm{r}}$ term becomes the height of the water column, $h_{w}$ above the bottom of the reservoir in the borehole, and $Q$ is the estimated reservoir volume. The volume estimate includes only water that is accessible to the borehole. Any water that is down dip or not in direct hydraulic connection to the borehole is not considered in the reservoir-volume estimate.

Application of this method and a more detailed discussion of a possible conceptual model of the system is presented in the "Analysis and Results" section for borehole USW SD-7.

\section{GENERAL HYDROGEOLOGIC CONDITIONS}

The ash-flow and air-fall tuffs that comprise the uppermost water-bearing units in the Yucca Mountain area vary from non- to densely welded. Although there have been no attempts to identify and quantify what part of the boreholes are producing water during pumping, the majority of flow occurs through fractures in several Yucca Mountain boreholes (Craig and Robison, 1984; Erickson and Waddell, 1985).

Relatively unfractured nonwelded, bedded, and reworked tuff are also present, and the rock matrix could potentially provide flow to the borehole.

The Yucca Mountain area is arid and no significant precipitation occurred during any of the testing periods. Depth-to-water (DTW) at the boreholes ranged between $347.5 \mathrm{~m}$ and $480.1 \mathrm{~m}$. The time for infiltration of any surface precipitation to the waterbearing zones is considered too long to produce an impact on water levels at these depths. Discharged water was piped a minimum of $90 \mathrm{~m}$ away from the pumped borehole into a downgradient surface drainage or stored in onsite tanks. There were no discharging wells within several kilometers of the boreholes being tested. The nearest perennial surface water is several kilometers from the pumped boreholes. Due to these conditions, no significant human-induced or precipitation-induced effects on the water levels occurred during aquifer testing. Passing 
weather fronts commonly produce barometricpressure changes that can have relatively minor effects (generally less than $0.15 \mathrm{~m}$ ) on water levels in Yucca Mountain boreholes. Barometric effects on water levels were accounted for by assuming a barometric efficiency of 100 percent for boreholes USW WT-10 and UE-25 WT\#12.

\section{AQUIFER TESTS}

Three boreholes in the Yucca Mountain area were pumped between March 1995 and January 1996. All boreholes were similar in that they had saturated thicknesses that are relatively thin compared to other deep boreholes at Yucca Mountain. Boreholes USW WT-10 and UE-25 WT\#12 have $83 \mathrm{~m}$ and $53 \mathrm{~m}$ of drilled penetration into the saturated zone. These boreholes primarily were drilled to monitor watertable levels and fluctuations.

No previous hydrologic testing had been done in these boreholes, so the degree to which the boreholes would produce water during pumping was unknown. If a network of transmissive fractures was penetrated by the borehole, significant volumes of water could be produced. If transmissive fractures were not penetrated, the borehole may not be able to produce enough water for aquifer testing.

Borehole USW SD-7 was drilled primarily to obtain physical rock properties. During the course of drilling and coring, a substantial volume of water was found above the regional water table. Drilling operations ceased, and the borehole was made available for aquifer testing of the apparent perchedwater body. Flow into the borehole was sufficient to support low discharge-rate pumping for several days.

\section{Borehole USW WT-10}

\section{Background}

Borehole USW WT-10 is located west of Yucca Mountain (fig. 1). The Topopah Spring Tuff was penetrated by and tested in borehole USW WT-10 (Robison and others, 1988). The borehole is open to the aquifer with no casing or screen below the water table. The borehole configuration is presented in table 1 .

The following is a brief geologic description of the borehole (R. Spengler, U.S. Geological Survey, written commun., 1995):

Topopah Spring Tuff: (321.0-384.0 m) Tuff, ashflow, light-brown, pale-red, and very light gray (mottled), densely welded, devitrified; pumice, commonly very light gray, devitrified; 1 to 2 percent phenocrysts (sanidine and biotite); fragments consisting of high temperature quartz; base of interval inferred from a progressive increase on density log.

(384.0-430.4 m) Tuff, ash-flow, light-brown, darkyellowish-brown, and moderate-brown, densely welded, devitrified; pumice, commonly lightbrown, devitrified; less than 1 percent phenocrysts (sanidine and biotite).

A suite of geophysical logs is available for this borehole and is described by Nelson and others (1991). No previous hydrologic investigations have been conducted at this borehole. The data and analysis presented in this report are the only available estimates of specific capacity and transmissivity.

Table 1. Summary of borehole USW WT-10 completion

\begin{tabular}{ccccccc}
\hline $\begin{array}{c}\text { Borehole location } \\
\text { (latltude } \\
\text { longltude) }\end{array}$ & $\begin{array}{c}\text { Total } \\
\text { depth } \\
\text { (meters) }\end{array}$ & $\begin{array}{c}\text { Depth of } \\
\text { caslng } \\
\text { (meters) }\end{array}$ & $\begin{array}{c}\text { Drllled } \\
\text { borehole } \\
\text { dlameter } \\
\text { (meters) }\end{array}$ & $\begin{array}{c}\text { Interval } \\
\text { tested } \\
\text { (meters) }\end{array}$ & $\begin{array}{c}\text { Interval } \\
\text { thlckness } \\
\text { (meters) }\end{array}$ & $\begin{array}{c}\text { Formation In } \\
\text { saturated Interval of } \\
\text { borehole }\end{array}$ \\
\hline $\begin{array}{c}36^{\circ} 48^{\prime} 25^{\prime \prime} \mathrm{N} \\
116^{\circ} 29^{\prime} 05^{\prime \prime} \mathrm{W}\end{array}$ & 431 & 35 & 0.222 & $348-431$ & 83 & Topopah Spring Tuff \\
\hline${ }^{1}$ Top of interval is the water table; bottom of interval is total depth.
\end{tabular}




\section{Aquifer Tests}

Data collection and aquifer testing were initiated at USW WT-10 on January 9, 1996, and concluded on January 22, 1996. An access tube for monitoring water levels and a progressive-cavity pump were installed in the borehole. A calibrated pressure transducer was installed and checked to ensure that it was accurately recording changes in water level. Pump discharge was measured with a calibrated in-line flowmeter and by a volumetric method in which the time to fill a known volume was measured. Volumetric-discharge measurements were used as the standard for pump-discharge rate during aquifer testing. The depth to water before and at the conclusion of testing was measured with a calibrated steel tape and was $347.3 \mathrm{~m}$.

At the initiation of pumping, it was apparent that the maximum discharge rate was less than optimal because the maximum drawdown was less than $0.4 \mathrm{~m}$. The pump was able to produce a maximum discharge of only $4.8 \mathrm{~L} / \mathrm{s}$, and no higher-capacity pumps were available. The borehole would respond to pumping with a rapid drop in water level, followed by a slightly descending trend for the remainder of the pumping period. Several tests were conducted at the maximum discharge rate with similar results.

Due to the small amount of drawdown and apparent high transmissivity, the borehole recovered almost instantaneously upon termination of pumping. Sufficient recovery data are, therefore, not available for analysis.

After the first day of pumping, the pump operators became concerned about pump damage and wear. The operators insisted on slowly increasing the flow at the start of a testing period until it reached the maximum rate. The slow increase in discharge appeared to have had an effect on the testing results and is discussed in the "Analysis and Results" section.

Due to logistical problems, manpower limitations, and other project commitments, a long-term aquifer test was not conducted in this borehole. Three tests were conducted for about 5 hours each, and one step-drawdown test (test 4) was conducted with 4 steps of about 1 hour each. Because of the short periods of pumping, variable discharge rates, and equipment testing, the first two days of pumping (test 1) were not analyzed. After reaching the maximum discharge rate, tests 2,3 , and 5 were conducted as constant-discharge tests. A summary of all of the pumping periods are presented in table 2.

Water-level fluctuations due to barometric pressure were accounted for by assuming that the borehole had a barometric efficiency of 100 percent. This assumption was reasonable, given observations of the static and pumping water-level fluctuations due to barometric-pressure fluctuations. The borehole and water surface are open to the atmosphere for the entire

Table 2. Summary of borehole USW WT-10 aquifer testing, January 9-22, 1996

\begin{tabular}{|c|c|c|c|c|c|}
\hline Date & $\begin{array}{c}\text { Test } \\
\text { number }\end{array}$ & $\begin{array}{l}\text { Time pump } \\
\text { on/off }\end{array}$ & $\begin{array}{l}\text { Duration of } \\
\text { pumplng } \\
\text { (hours) }\end{array}$ & $\begin{array}{c}\text { Mean } \\
\text { discharge } \\
\text { (ilters/second) }\end{array}$ & $\begin{array}{c}\text { Dally } \\
\text { dlscharge } 1 \\
\text { (liters) }\end{array}$ \\
\hline $1 / 9 / 96$ & 1 & $14: 30 / 15: 17$ & 0.8 & $\begin{array}{c}\text { Testing pump } \\
(3.3-4.8)\end{array}$ & 10,200 \\
\hline \multirow[t]{2}{*}{$1 / 10 / 96$} & 1 & $11: 15 / 11: 20$ & 0.1 & -- & -- \\
\hline & & $14: 25 / 15: 40$ & 1.3 & 4.8 & 21,600 \\
\hline $1 / 11 / 96$ & 2 & $10: 00 / 14: 45$ & 4.8 & 4.78 & 81,800 \\
\hline $1 / 16 / 96$ & 3 & $09: 48 / 14: 50$ & 5.0 & 4.76 & 86,300 \\
\hline \multirow[t]{5}{*}{$1 / 17 / 96$} & 4 & 09:50/10:04 & 0.2 & -- & -- \\
\hline & & $10: 05 / 11: 01$ & 0.9 & 1.26 & 4,200 \\
\hline & & $11: 02 / 12: 03$ & 1.0 & 2.62 & 9,500 \\
\hline & & $12: 04 / 13: 00$ & 0.9 & 3.72 & 12,500 \\
\hline & & $13: 01 / 14: 42$ & 1.7 & 4.75 & 28,800 \\
\hline $1 / 18 / 96$ & 5 & 09:49/14:41 & 4.9 & 4.65 & 81,400 \\
\hline Totals ${ }^{1}$ & -- & -- & 21.6 & -- & 336,100 \\
\hline
\end{tabular}

${ }^{1}$ Values in table have been rounded; daily discharge and totals were calculated from original values. 
length of the borehole, so there was no attenuation of barometric pressure at the water table because of the unsaturated zone or borehole construction.

The drawdown data show high-frequency fluctuations that are probably due to the pump (figs. 2-5). The pump probably did not have constant discharge because of the basic design, generatorvoltage fluctuations, and control-drive efficiency. The discharge fluctuations could be causing a surging action in the water column. Physical movement of the pump string in the borehole could also be adding to the water-level fluctuations. These factors probably contribute to the erratic nature of the water level during pumping.

Linear-regression analysis was used to obtain the best-fit straight line through the drawdown data. Data that were collected after the pumping rate had stabilized were used in the regression analysis. The slope of the best-fit straight line, the drawdown at the end of pumping, and estimates of the drawdown at the end of 24 hours of pumping were obtained from the regression analysis.

Volumetric-discharge measurements were obtained by measuring the time for pumped water to fill a container of known volume, and were used to determine the mean pump-discharge rate for tests 1,2 , 4 , and 5. During test 3 , however, manual dischargemeasurements were substantially lower than the flowmeter-discharge rate, which indicated that the rate was similar to the previous tests. The mean dischargerate for test 3 was based on flowmeter data and pump performance throughout testing.

\section{Analysis and Results}

\section{Borehole Storage}

The time at which borehole storage was assumed to be negligible was calculated using equation 1. Aquifer tests 2,3 , and 5 were conducted at virtually the same discharge rate $(4.6-4.8 \mathrm{~L} / \mathrm{s})$ and with the same borehole and pump configuration. Borehole storage effects should, therefore, be negligible at the same time for each of the three tests. The borehole diameter was assumed to be $300 \mathrm{~mm}$, and the pump-column pipe outside diameter was assumed to be $95 \mathrm{~mm}$. Using a conservative discharge rate of $3.15 \mathrm{~L} / \mathrm{s}$ and the small observed drawdown, borehole storage is negligible after only 2 minutes of pumping and is not a concern during the aquifer tests.

\section{Constant Discharge Tests}

Three constant discharge tests were conducted in borehole USW WT-10, and the data were analyzed using three different methods. The straight-line method was used to determine transmissivity for tests 2,3 , and 5 . Specific capacity was determined and used in an ASTM (1993) method to estimate transmissivity. The pumping portion of all three tests was approximately 5 hours, and discharge was at the maximum rate possible.

Determination of specific yield is not presented because of the unreliable results, which could have been caused by the variable borehole radius in USW WT-10 (Lohman, 1979, p. 25). A reasonable value for specific yield in an unconfined, fractured-rock aquifer of 0.01 (Freeze and Cherry, 1979) was assumed when needed to determine transmissivity with the ASTM method.

The pump was not started at the maximum discharge rate during testing. The time to reach maximum discharge ranged from about 10 to 50 minutes in tests 2,3 , and 5 . The variable discharge appeared to affect the early-time drawdown, which may have been differentially affected by water-table drainage. If flow was occurring from a small portion of the fractured rock aquifer, which has minor storage capacity, reasonably complete drainage should have occurred fairly rapidly.

\section{Straight-ilne anaiysis}

Aquifer tests 2, 3, and 5 were analyzed with the straight-line method. In order to properly apply the straight-line method, the borehole must be pumped for sufficient time to reduce the value of $u$ to less than 0.01 . Rearranging and solving equation 3 for time ( $t)$, with conservative estimates of specific yield $(0.1)$, transmissivity ( $100 \mathrm{~m}^{2} /$ day), and borehole radius $(0.2 \mathrm{~m})$, the time at which $u$ is equal to 0.01 is less than 2 minutes. The requirement that $u$ be less than 0.01 is met almost immediately upon pumping in borehole USW WT-10.

The straight-line analysis requires that the data be plotted on a semi-logarithmic time scale. The bestfitting straight line was determined from linearregression analysis on the data collected while the pump was operating at the maximum, constant discharge rate. Transmissivity was then calculated (eq. 2) based on the slope of the line, which is the change in drawdown over one log-cycle $(\Delta s)$. 


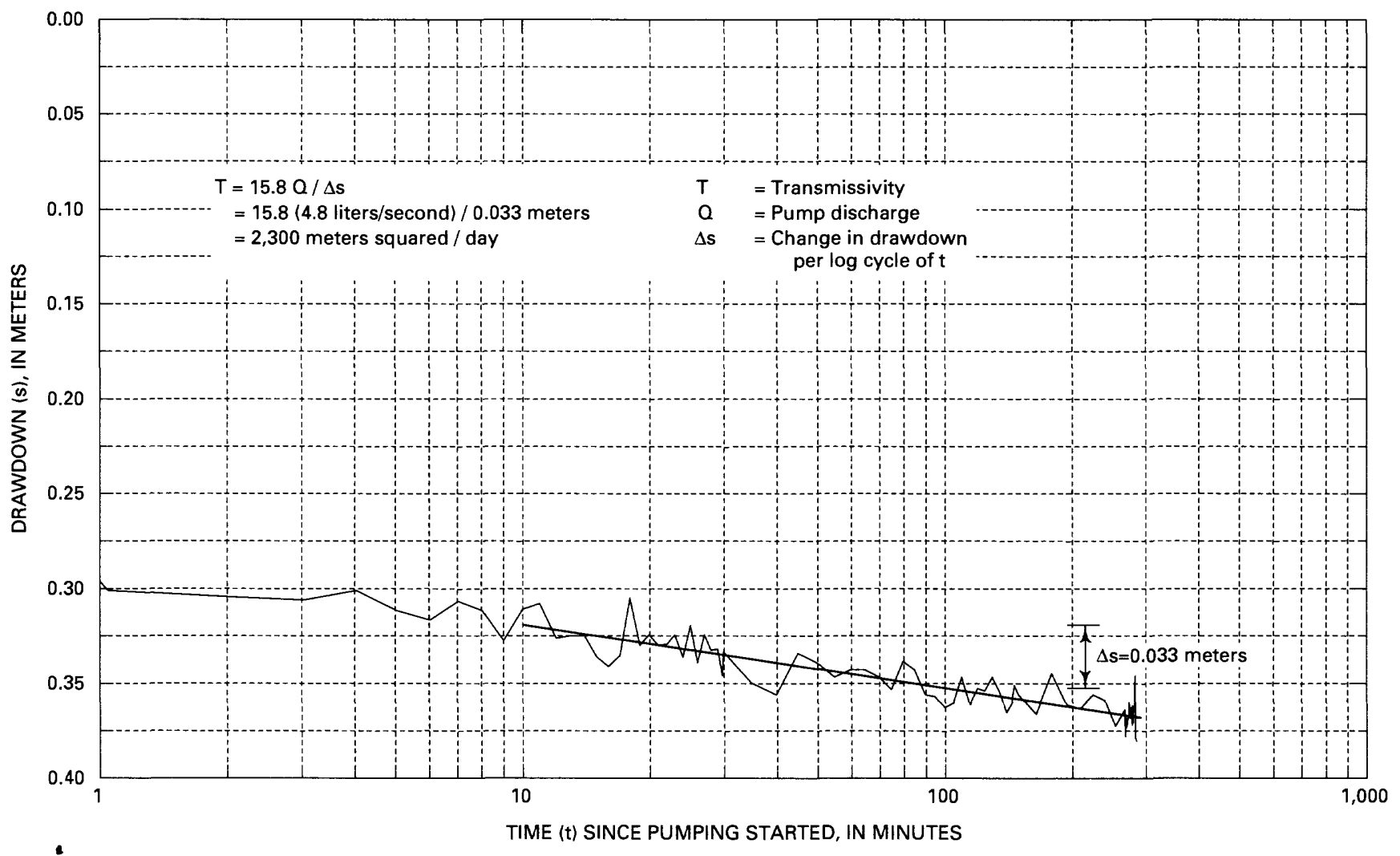

Figure 2. Aquifer-test analysis by straight-line analytical solution for drawdown data during test 2 , January 11,1996 , in borehole USW WT-10.

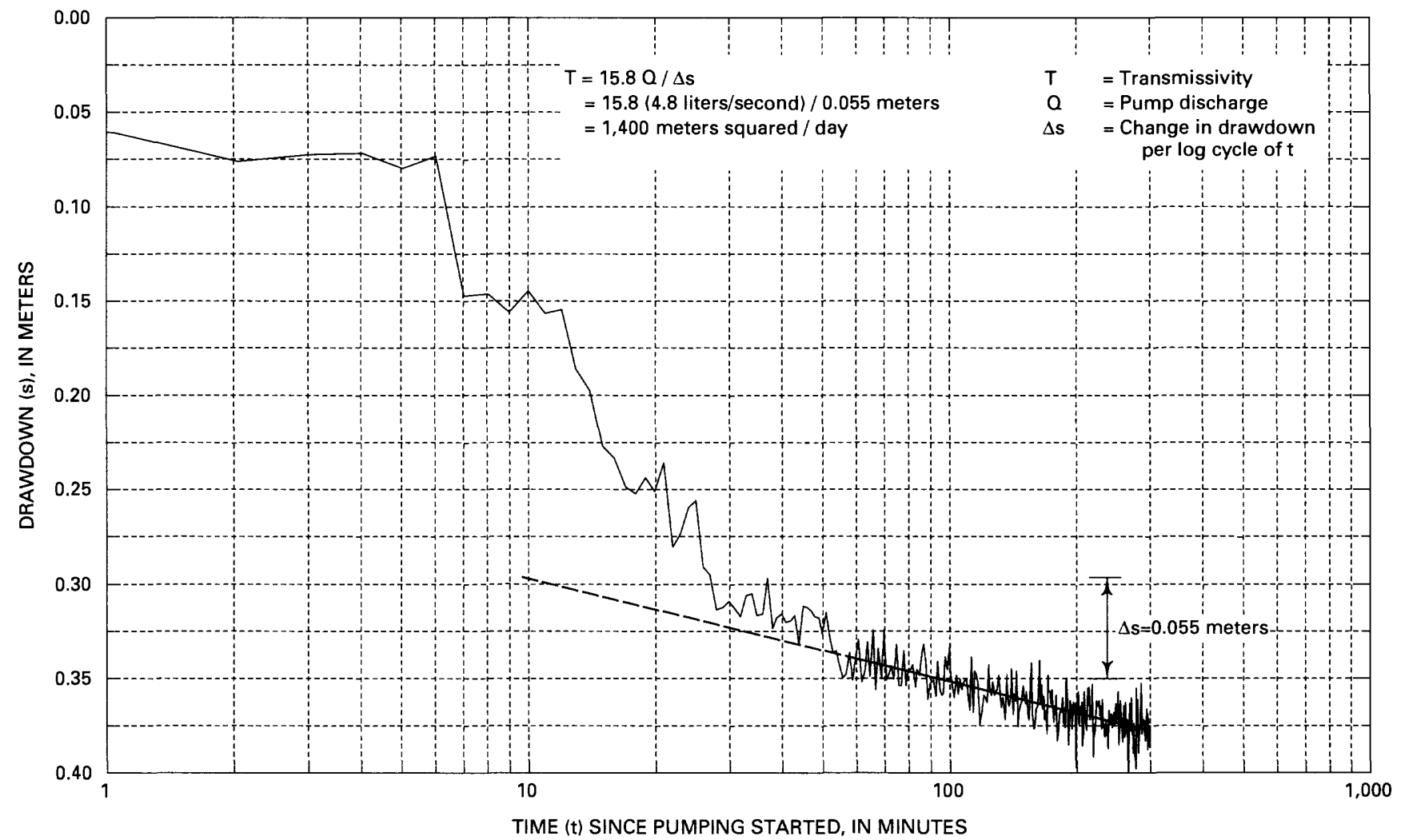

Figure 3. Aquifer-test analysis by straight-line analytical solution for drawdown data during test 3 , January 16,1996 , in borehole USW WT-10. 


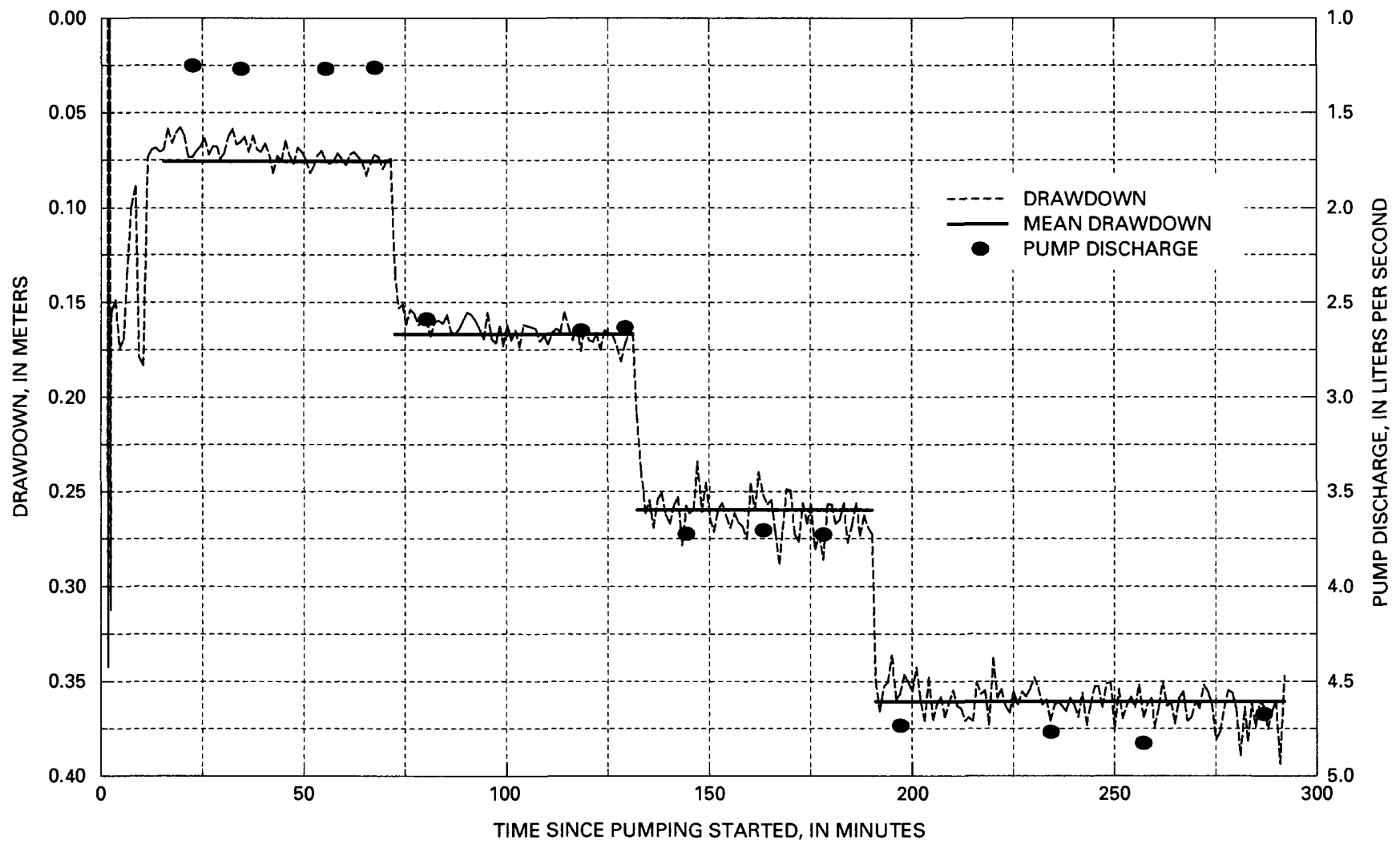

Figure 4. Drawdown and discharge as a function of time during step-drawdown test 4, January 17, 1996, in borehole USW WT-10.

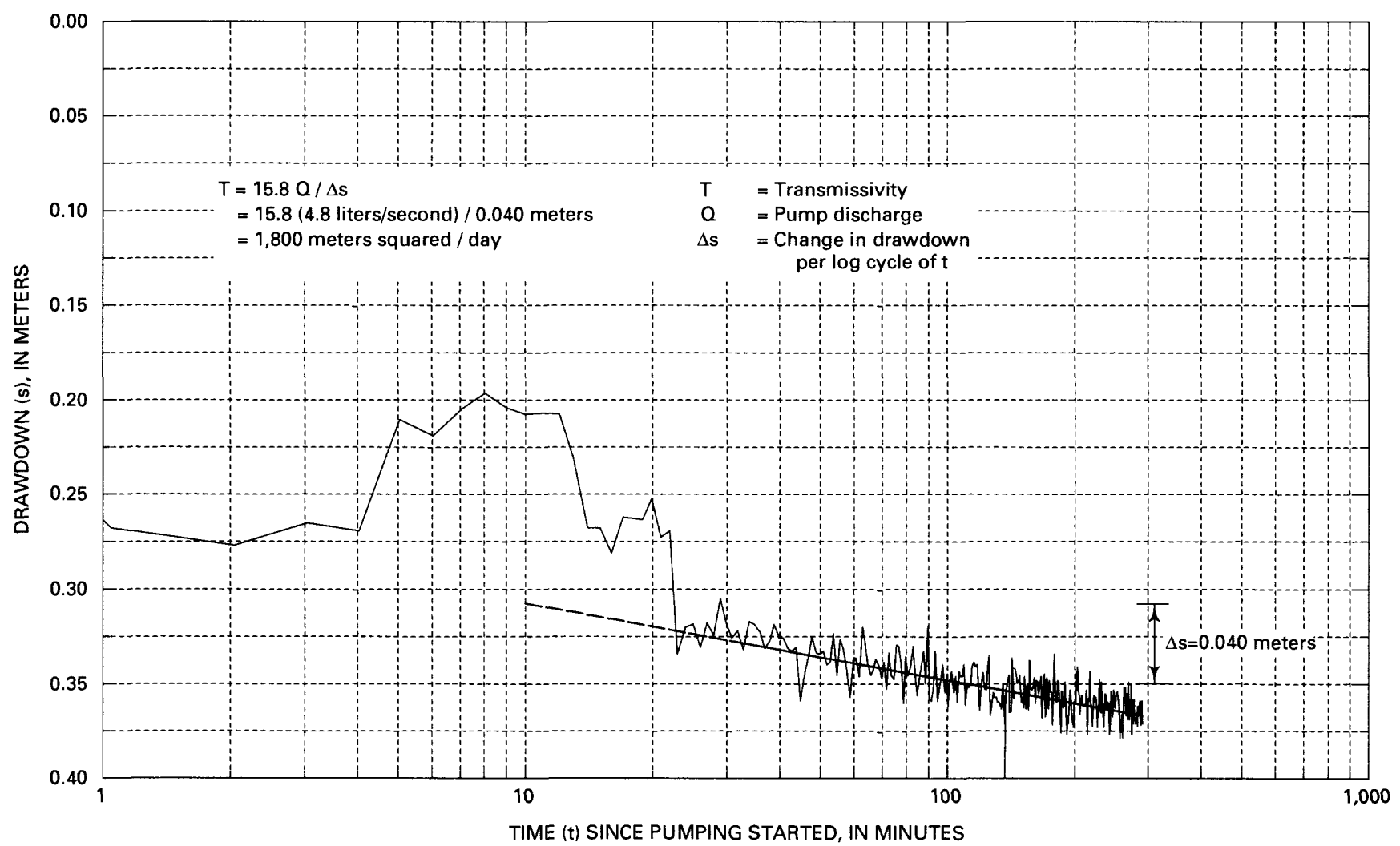

Figure 5. Aquifer-test analysis by straight-line analytical solution for drawdown data during test 5 , January 18,1996 , in borehole USW WT-10. 
Straight-line analysis and results are presented individually on figures 2,3 , and 5 , and summarized in table 3 .

Tabie 3. Summary of transmissivity determined with straight-line and ASTM methods for borehole USW WT-10

[-, no data; ASTM, American Society for Testing Materials]

\begin{tabular}{clcr}
\hline \multirow{2}{*}{ Test number } & $\begin{array}{c}\text { Method of } \\
\text { analysis }\end{array}$ & \multicolumn{2}{c}{$\begin{array}{c}\text { Transmissivity } \\
\text { (meters }\end{array}$} \\
\cline { 3 - 4 } & & 5 -hour & 24-hour \\
\hline 2 & Straight-line & 2,300 & -- \\
2 & ASTM & 1,300 & 900 \\
3 & Straight-line & 1,400 & -- \\
3 & ASTM & 1,300 & 900 \\
5 & Straight-line & 1,800 & -- \\
5 & ASTM & 1,300 & 1,000 \\
Mean & Straight-line & 1,800 & -- \\
& ASTM & 1,300 & 930 \\
\hline
\end{tabular}

\section{Specific-capacity analysis}

Specific capacity was calculated based on the drawdown at the end of pumping, as determined from the linear-regression analysis and the mean discharge for each test. The drawdown at the end of 5 hours of pumping was virtually equal for tests 2,3 , and 5 , which resulted in similar specific-capacity values (table 4).
It is common practice to report specific-capacity values after 24 hours of pumping. Borehole USW WT-10 was not pumped for 24 hours, so 24-hour specific capacity was estimated with linearregression analysis to extrapolate the drawdown curve. The analysis results, including discharge and drawdown values used, are presented in table 4. Use of the 24-hour specific-capacity value is beneficial when comparing the relative performance of boreholes.

\section{American Society for Testing Materlals Method}

Due to the short pumping periods used in the straight-line analysis and the potential for errors due to water-table drainage, transmissivity was also determined with the ASTM method. Specific-capacity values presented in table 4 were used in an iterative process of solving the modified Theis nonequilibrium equation (eq. 5) as discussed in the "Methods of Analysis" section. Specific yield was assumed to be 0.01 for use in solving equation 3 for $u$. An order of magnitude error in the estimation of specific yield would result in an error of about 15 percent in the calculated transmissivity. Advantages of the ASTM method are that water-table drainage should have decreased after 5 hours of pumping and that the drawdown values were similar for all tests.

Transmissivity estimates are valid only for the saturated thickness of the borehole, not the entire

Tabie 4. Summary of specific capacity obtained from aquifer tests $2,3,4$, and 5 in borehole USW WT-10

$[-$, no data $]$

\begin{tabular}{|c|c|c|c|c|c|}
\hline \multirow{2}{*}{$\begin{array}{c}\text { Test number/step } \\
\text { number }\end{array}$} & \multirow{2}{*}{$\begin{array}{c}\text { Mean } \\
\text { discharge } \\
\text { (ilters/second) }\end{array}$} & \multicolumn{2}{|c|}{$\begin{array}{l}\text { Drawdown after: } \\
\text { (moters) }\end{array}$} & \multicolumn{2}{|c|}{$\begin{array}{c}\text { Specific capacity after: } \\
\text { (meters }{ }^{2} / \text { day) }\end{array}$} \\
\hline & & 5 hours & 24 hours $^{\top}$ & 5 hours & 24 hours \\
\hline 2 & 4.78 & 0.37 & 0.56 & 1,100 & 740 \\
\hline 3 & 4.76 & 0.38 & 0.60 & 1,100 & 690 \\
\hline $4 / 1$ & 1.26 & ${ }^{2} 0.08$ & -- & ${ }^{2} 1,400$ & $\cdots$ \\
\hline $4 / 2$ & 2.62 & ${ }^{2} 0.17$ & -- & ${ }^{2} 1,400$ & -- \\
\hline $4 / 3$ & 3.72 & ${ }^{2} 0.26$ & -- & ${ }^{2} 1,200$ & -- \\
\hline $4 / 4$ & 4.75 & ${ }^{2} 0.36$ & -- & ${ }^{2} 1,100$ & -- \\
\hline 5 & 4.65 & 0.37 & 0.51 & 1,100 & 790 \\
\hline Mean (tests 2, 3, and 5) & -- & -- & -- & 1,100 & 740 \\
\hline
\end{tabular}


aquifer. The total thickness of the Topopah Spring Tuff was not penetrated by the borehole, so the saturated thickness (b) is unknown. No attempt was made to obtain hydraulic conductivity $(\mathrm{K})$ for the tested interval and then convert it to transmissivity $(T=K b)$ for the entire formation. Because of the highly heterogeneous nature of fractured-rock aquifers, it is possible that additional penetration into the formation could have produced significantly different results.

A summary and comparison of transmissivity values determined with the straight-line and ASTM methods are presented in table 3 . The transmissivity values obtained with the straight-line method are consistently higher than those obtained by the ASTM method. The slope of the best-fit line used in the straight-line analysis may have been affected by the variable discharge rate at the start of pumping. If drainage from aquifer storage was occurring, it would result in an apparent increase in transmissivity by reducing the slope of the drawdown curve. The ASTM method results may be more reliable because they are based on the latest time data available and, therefore, are not as highly influenced by water-table drainage. It should be noted that because the ASTM method results are based on specific capacity, which decreases with increasing pumping time, the calculated transmissivities also decrease with time.

Analysis of aquifer tests in borehole USW WT-10 was affected by the less than ideal conditions of small drawdown and short pumping duration. The accuracy of the 24-hour specific-capacity estimates cannot be determined, and significant error could be present. It is doubtful that the drawdown rate would change significantly when the borehole was being pumped at a discharge rate that was far below its maximum yield. Transmissivities determined from the 24-hour specific-capacity estimates are within the range of estimates determined in other Yucca Mountain area wells (Thordarson, 1983; Thordarson and Howells, 1987; Plume and La Camera, 1996). Additional aquifer tests at higher discharge rates are needed to better define the transmissivity at this site.

\section{Step-Drawdown Test}

A step-drawdown test (test 4) with four steps of about 1 hour each, in which the discharge rate was incrementally increased, was conducted in borehole USW WT-10. Test 4 data were used to determine specific capacity and estimate borehole efficiency.
Step-drawdown and discharge data are presented in figure 4. The slope of the drawdown curve for each step was essentially zero, so the mean drawdown for each step was used in the analysis. Mean discharge was calculated for the individual steps based on the volumetric-discharge measurements.

Driscoll (1986, p. 558) describes how to use the modified Theis nonequilibrium equation to determine borehole efficiency with the actual 1-day specific capacity divided by the theoretical specific capacity. Using a transmissivity of $1,600 \mathrm{~m}^{2} /$ day and specific yield of 0.01 , the borehole efficiency was 63 percent, which indicates that the borehole is reasonably efficient and that head losses probably did not invalidate the transmissivity estimates. Because of the small range in discharge and the minimal drawdown that could be obtained during the test, these results probably are useful only as qualitative information.

\section{Summary of Results}

Mean specific capacity after 5 hours of pumping was $1,100 \mathrm{~m}^{2} /$ day, and after 24 hours of pumping, was estimated to be $740 \mathrm{~m}^{2} /$ day. The best estimate of transmissivity for this borehole, based on the available data, is $1,600 \mathrm{~m}^{2} /$ day, which is the mean of the straight line and the 5-hour ASTM method results. The conditions during aquifer testing did not test a large part of the aquifer, and the results could be misleading. In order to stress the aquifer and test more of the formation, it would be necessary to obtain discharge rates in the 10 to $30 \mathrm{~L} / \mathrm{s}$ range. A long-term aquifer test at a higher discharge rate is needed to ensure that the data are not significantly affected by water-table drainage. It is apparent that the Topopah Spring Tuff in this borehole has a relatively high transmissivity compared to the same formation in borehole UE-25 WT\#12.

\section{Borehole UE-25 WT\#12}

\section{Background}

Borehole UE-25 WT\#12 is located at the southern end of Yucca Mountain (fig. 1). The Topopah Spring Tuff and the Calico Hills Formation were penetrated by and tested in borehole UE-25 WT\#12 (Robison and others, 1988). The borehole is open to the aquifer with no casing or screen below the water table. The borehole configuration is presented in table 5 . 
Table 5. Summary of borehole UE-25 WT\#12 completion

\begin{tabular}{cccccc}
\hline $\begin{array}{c}\text { Borehole location } \\
\text { (latltude } \\
\text { longltude) }\end{array}$ & $\begin{array}{c}\text { Total depth } \\
\text { (meters) }\end{array}$ & $\begin{array}{c}\text { Drilled-borehole } \\
\text { diameter } \\
\text { (meters) }\end{array}$ & $\begin{array}{c}\text { Interval } \\
\text { tested } \\
\text { (meters) }\end{array}$ & $\begin{array}{c}\text { Interval } \\
\text { thickness } \\
\text { (meters) }\end{array}$ & $\begin{array}{c}\text { Formations In saturated } \\
\text { Interval of the borehole }\end{array}$ \\
\hline $36^{\circ} 46^{\prime} 56^{\prime \prime} \mathrm{N}$ & 399 & 0.222 & $346-399$ & 53 & $\begin{array}{c}\text { Topopah Spring Tuff (41 m) and } \\
\text { Calico Hills Formation (12 m) }\end{array}$ \\
$116^{\circ} 26^{\prime} 16^{\prime \prime} \mathrm{W}$ & & & & &
\end{tabular}

${ }^{1}$ Top of interval is the water table; bottom of interval is total depth.

The following geologic description of the borehole was provided by R. Spengler (U.S. Geological Survey, written commun., 1995).

Topopah Spring Tuff: (326.1(?)-349.0 m) Tuff, ash-flow, pale-yellowish-brown, dark-yellowishbrown and grayish orange, densely welded, devitrified [slightly altered (?)]; pumice, commonly grayish-orange, devitrified [slightly altered (?)]; less than 1 percent phenocrysts (sanidine); bit cutting sample extremely fine grained, commonly less than $2 \mathrm{~mm}$ in size.

(349.0-359.7 m) Tuff, ash-flow, black and lightolive-gray, densely welded, glassy (vitrophyre); less than 1 percent phenocrysts (sanidine); base of interval at an abrupt decrease on density log.

(359.7-381.0 m) Tuff, ash-flow, light-brown to moderate-brown, partially welded to nonwelded, predominately zeolitic (?) (partially vitric), pumice, light-brown, commonly zeolitic (?); rare sanidine and biotite phenocrysts; base of interval at an abrupt decrease on density log.

(381.0-387.1 (?) ft) Bedded tuff, ash-fall, very pale orange, poorly consolidated; predominately composed of coarse-grained very pale orange pumice clasts, most appear altered to zeolites (?), vitric; some quartz phenocrysts.

Calico Hills Formation: (387.1 (?)-398.7 m) Tuff, ash-flow, grayish-orange-pink, nonwelded, zeolitic (?); pumice, yellowish-gray to dusky-yellow, zeolitic (?); 1 percent phenocrysts (sanidine and biotite); sparse dark-gray and pale-red volcanic lithic fragments; bedded tuff interval from 366.58 to $398.62 \mathrm{~m}$, dipping 17 degrees; bedded tuff, palereddish-brown, predominately yellowish-gray, zeolitic pumice fragments (subrounded); rare sanidine and biotite; sparse, minute dark-gray volcanic lithic fragments.
A suite of geophysical logs are available for this borehole and are described in Nelson and others (1991). No previous hydrologic investigations have been conducted at this borehole. The data and analysis presented in this report are the only available estimates of specific capacity and transmissivity.

\section{Aquifer Tests}

Borehole UE-25 WT\#12 was equipped with a data-acquisition system and a progressive-cavity pump from August 17 to September 19, 1995. During this period, the borehole was extensively pumped in an attempt to determine the aquifer transmissivity. A calibrated pressure transducer was installed and checked to ensure that it was accurately recording changes in water level. Pump discharge was measured about every hour with a manual method in which the time to fill a known volume was measured. The depth to water before and at the conclusion of testing was measured with a calibrated steel tape as $345.35 \mathrm{~m}$ and $345.23 \mathrm{~m}$.

The borehole was initially pumped in several cycles, at many discharge rates, in an attempt to develop the borehole and to determine a discharge rate that could be sustained for several days. It was difficult to determine if the borehole was being developed or was merely sensitive to changes in discharge. Changes in discharge of less than $0.3 \mathrm{~L} / \mathrm{s}$ would dramatically change the rate of drawdown. For example, pumping could proceed for several days at a discharge rate of $1.3 \mathrm{~L} / \mathrm{s}$, but if the discharge rate was increased by $0.3 \mathrm{~L} / \mathrm{s}$, pumping would have to be stopped in a few hours due to the water level reaching the pump intake. Mean discharge during test 6 was $0.02 \mathrm{~L} / \mathrm{s}$ higher than during test 8 , but there was nearly $3.4 \mathrm{~m}$ more drawdown after 48 hours of pumping. Discharge rates between 0.9 and $4.4 \mathrm{~L} / \mathrm{s}$ were tried prior to determination of an optimal rate of about $1.3 \mathrm{~L} / \mathrm{s}$ for long-term aquifer tests. There were no 
constant-rate tests at discharge greater than $1.3 \mathrm{~L} / \mathrm{s}$ that lasted long enough to be reliably analyzed.

Periods of pumping were divided into several tests to maintain a manageable reference to the data. A new test number was generally used for each day, or multiple days, of pumping. Test 4 , however, was started after the discharge rate was changed, because the data file was becoming too large for software used to analyze the data and test 7 contains two days of relatively short pumping periods. A summary of pumping duration and discharge rates is provided in table 6 for testing after the initial pump cycling (tests 1 and 2). Pumping was terminated for a variety of reasons, including reaching the maximum drawdown level (at the pump intake), generator failure, and planned termination.

\section{Analysis and Results}

Three tests were chosen for detailed analysis based on the length of pumping, uniform test conditions, and sufficient discharge measurements. Drawdown data were analyzed for tests 6,8 , and 9, and recovery data were analyzed for tests 6 and 9. Generator failure and electrical problems resulted in loss of the last 7.4 hours of drawdown data and all of the recovery data for test 8 . The Cooper and Jacob straight-line method and the ASTM method were used to estimate transmissivity for tests 6,8 , and 9. All tests were analyzed as constant-discharge tests. Tests
$3,4,5$, and 7 were not formally analyzed because of relatively short pumping cycles and variable discharge.

\section{Well Loss}

Drawdown sensitivity to discharge rate proved to be a significant aspect of the aquifer tests in borehole UE-25 WT\#12. During drawdown tests 6, 8, and 9, the water levels would rise and fall in a cyclic nature in addition to maintaining an overall downward trend (figs. 6, 7, and 8). The cyclic rise and fall of the drawdown curves was determined to be related to changes in discharge rate. The discharge rate would decrease slightly during the daylight hours and increase slightly during the night. A small, practically immeasurable change in discharge rate can cause significant change in the drawdown if well losses are high (Kawecki, 1995). The frequency and accuracy of the discharge measurements were sufficient to define the changing discharge rate. A decrease of $0.05 \mathrm{~L} / \mathrm{s}$ in the discharge rate could cause a decrease of about $0.5 \mathrm{~m}$ in drawdown. The correlation between drawdown and discharge during test 8 is illustrated in figure 9. There is a similar correlation between drawdown and discharge for tests 6 and 9. No corrections have been made to the drawdown data to remove the effects of changing discharge. The overall slope of the drawdown curve can be determined with the cyclic drawdown included in the data set.

Table 6. Summary of aquifer tests in borehole UE-25 WT\#12 for tests 3 through 9, August 19-September 15, 1995

\begin{tabular}{lcccc}
\hline \multicolumn{1}{c}{ Date } & $\begin{array}{c}\text { Test } \\
\text { number }\end{array}$ & $\begin{array}{c}\text { Time pump } \\
\text { on/off }\end{array}$ & $\begin{array}{c}\text { Duration of } \\
\text { pumping } \\
\text { (hours) }\end{array}$ & $\begin{array}{c}\text { Mean } \\
\text { discharge } \\
\text { (Ilters/second) }\end{array}$ \\
\hline $8 / 19 / 95$ & 3 & $0800 / 2130$ & 13.5 & 1.08 \\
$8 / 19-20 / 95$ & 3 & $2230 / 2030$ & 22.0 & 1.27 \\
$8 / 20-21 / 95$ & 4 & $2030 / 0451$ & 8.4 & 1.46 \\
$8 / 21 / 95$ & 5 & $1125 / 1305$ & 1.7 & 1.67 \\
$8 / 21 / 95$ & 5 & $1305 / 2137$ & 8.5 & 1.15 \\
$8 / 21 / 95$ & 5 & $2137 / 2230$ & 0.9 & 1.30 \\
$8 / 22-24 / 95$ & 6 & $0800 / 0800$ & 48.0 & 1.29 \\
$8 / 30 / 95$ & 7 & $1150 / 1600$ & 4.2 & 1.29 \\
$8 / 31 / 95$ & 7 & $0800 / 1600$ & 8.0 & 1.31 \\
$9 / 5-11 / 95$ & 8 & $1200 / \sim 1945$ & 151.8 & 1.27 \\
$9 / 11-15 / 95$ & 9 & $2100 / 1800$ & 93.0 & 1.27 \\
\hline
\end{tabular}




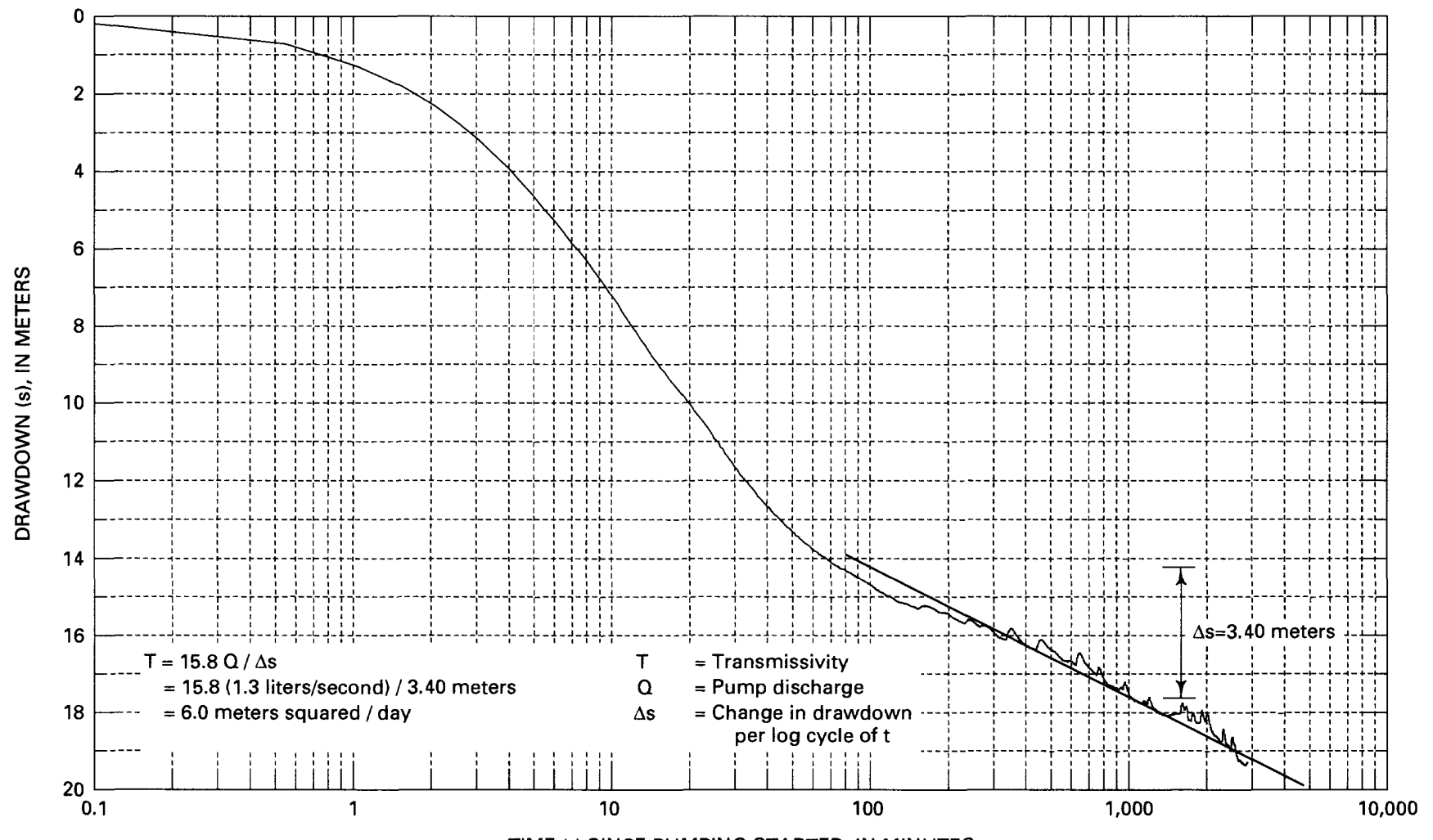

TIME (t) SINCE PUMPING STARTED, IN MINUTES

Figure 6. Aquifer-test analysis by straight-line analytical solution for drawdown data during test 6 , August 22-24, 1995, in borehole UE-25 WT\#12.

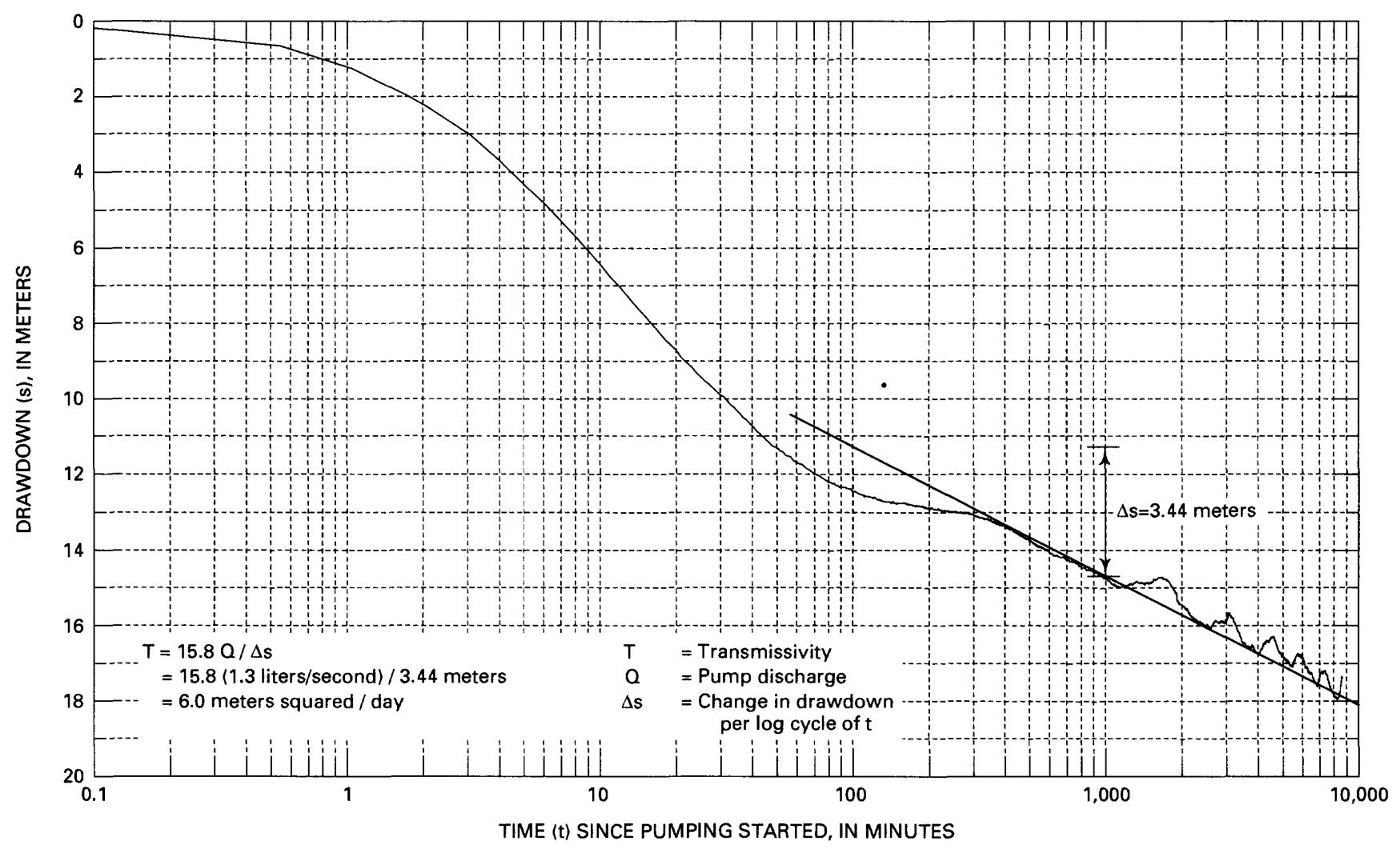

Figure 7. Aquifer-test analysis by straight-line analytical solution for drawdown data during test 8 , September 5-11, 1995, in borehole UE-25 WT\#12. 


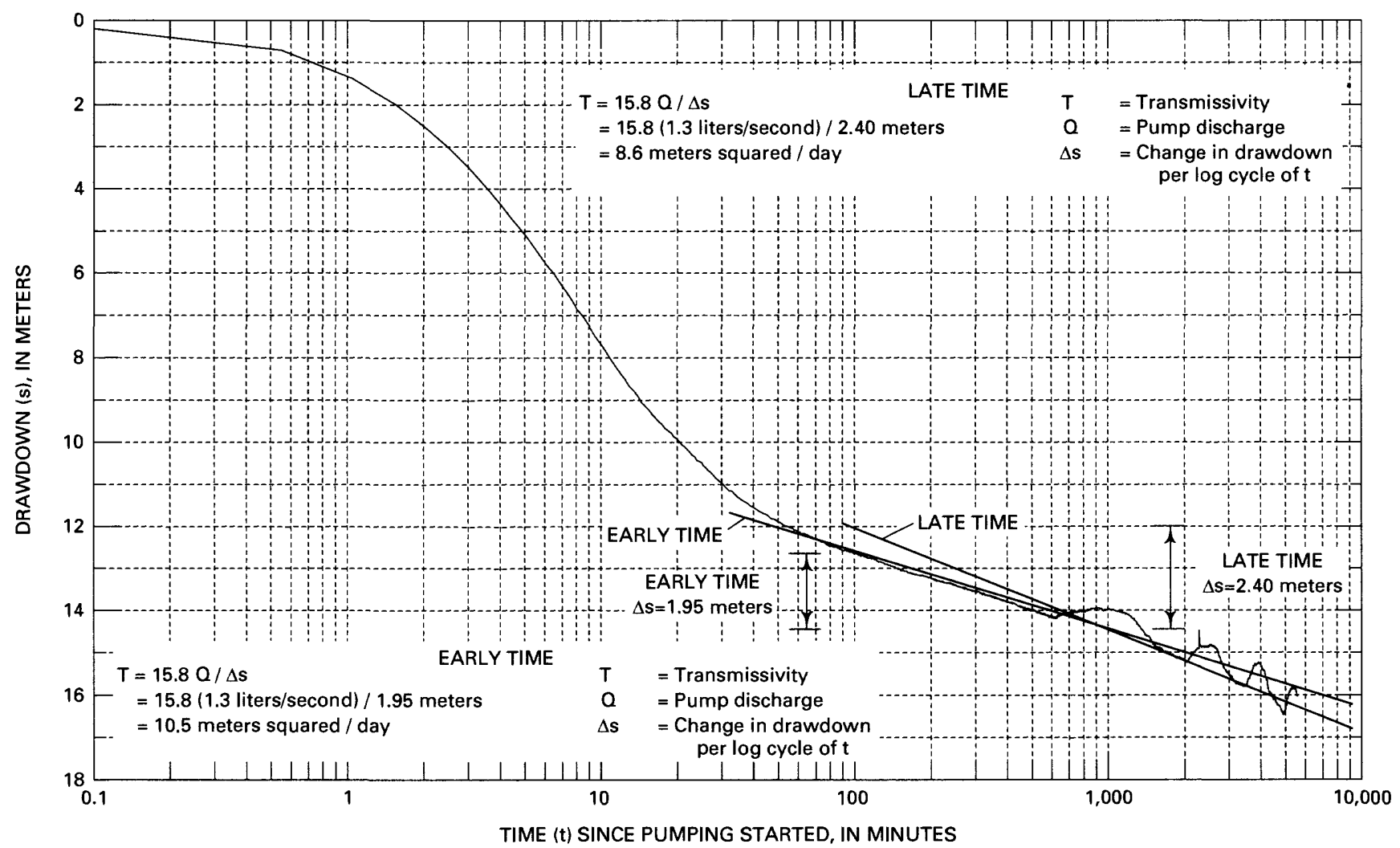

Figure 8. Aquifer-test analysis by straight-line analytical solution for drawdown data during test 9 , September $11-15,1995$, in borehole UE-25 WT\#12.

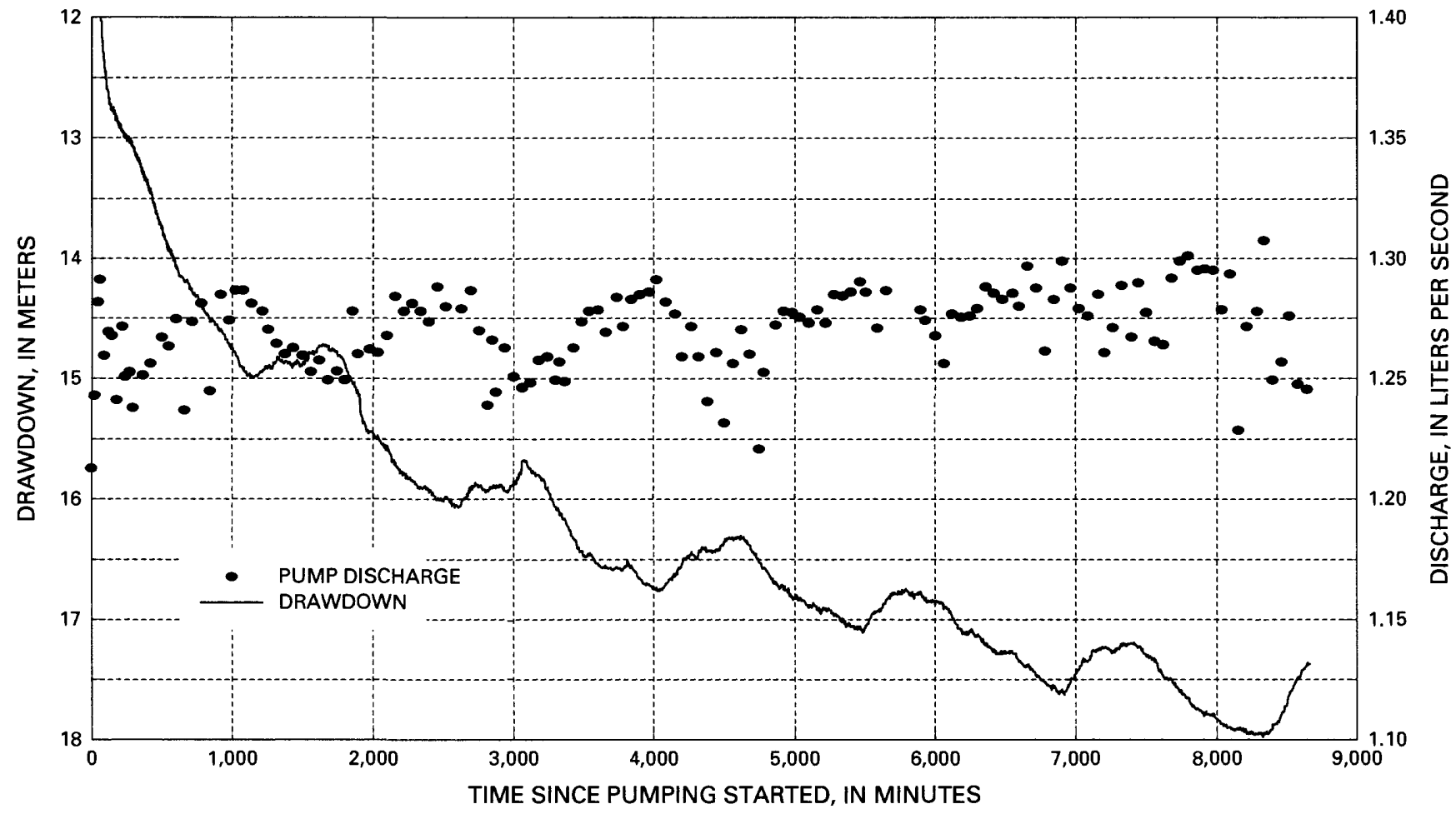

Figure 9. Drawdown and discharge fluctuations as a function of time during aquifer test 8, September 5-11, 1995, in borehole UE-25 WT\#12. 
Changes in the discharge rate on the order of $0.06 \mathrm{~L} / \mathrm{s}$ are probably related to pump and/or generator efficiency. The discharge rate would decrease during the hot, daylight hours and increase during the cooler, night-time hours. Increases in temperature may have affected the hydraulic drive on the pump or caused the generator to produce lower output voltage. All pumps generally have some variability in discharge rate, but only boreholes with high well losses are significantly affected by the normal, small changes in discharge.

The magnitude of the cyclic changes in drawdown are too large to be attributed to barometric pressure. Water levels in this borehole normally respond to barometric pressure with about 100 percent efficiency. The maximum possible water-level change during test 8 pumping, due to barometric pressure, would be less than $0.1 \mathrm{~m}$, which is much less than the $0.5 \mathrm{~m}$ fluctuations seen in the drawdown data. The impact of pumping appears to overwhelm and minimize any direct barometric pressure response in borehole UE-25 WT\#12. Correcting the drawdown data by assuming a barometric efficiency of 100 percent results in a small shift in the drawdown value, but the shape and slope of the curve remains the same.

Well loss is generally quantified through analysis of step-drawdown tests. Unfortunately, this borehole did not respond in step increments to changes in discharge. The drawdown would approximate a linear downward trend, and changes in discharge would merely change the slope of the trend. Regardless of the discharge rate, the drawdown would not reach an equilibrium level. As a result of these conditions, an analyzable step-drawdown test was not possible, and a quantitative assessment of well loss could not be completed.

Further evidence that well losses were high was illustrated in the recovery data. During various tests, the borehole was pumped between 0.9 hours and 6.3 days. At the conclusion of pumping, the borehole would completely recover within 30 minutes, independent of the length of the previous pumping and maximum drawdown. If the drawdown in the borehole is representative of the dewatering occurring in the water-table aquifer, the recovery time should be approximately equal to the pumping time. The rapid recovery probably indicates that only a small portion of the aquifer was dewatered during pumping and that a significant cone of depression had not developed around the borehole. Therefore, most of the recovery was a measure of borehole storage rather than of aquifer transmissivity.

The rapid recovery following pumping seen during aquifer testing in borehole UE-25 WT\#12 is often attributable to backflow from the pump. A check valve was installed on the pump to prevent water in the pump string from flowing into the borehole after pumping stopped. The pump string would remain full of water following several days of recovery, indicating that the check valve was functioning properly. The rapid recovery is a function of the borehole and aquifer conditions, and not because of equipment failure.

The drawdown portion of test 9 was another indication that the cone of depression was poorly developed. Test 8 pumping ended after 151.8 hours when the generator failed. Generator power was restored after 75 minutes and test 9 pumping was initiated. If a large cone of depression had developed during test 8 pumping, it would be expected that the borehole would not completely recover after only 75 minutes. If significant dewatering had occurred during the 151.8 hours of test 8 pumping, the drawdown during test 9 should resume dewatering the part of the aquifer that had not recovered. Instead, drawdown during test 9 was nearly a repeat of test 8 , indicating that the aquifer was probably fully recovered after only 75 minutes.

It is doubtful that borehole damage during drilling would cause such extreme responses to pumping and recovery. Given the fractured nature of the tuffaceous formations being tested, it is possible that the borehole only intersected secondary fractures that have transmissivities less than the primary fractures. The fractures in UE-25 WT\#12 appeared to produce the maximum volume of water possible given the fracture and hydraulic-head conditions. The situation is analogous to the capacity limits that a given diameter pipe has when transmitting water under a constant hydraulic head. The volume of water that could be transmitted through the secondary fractures was not enough to impact, or dewater, the primary-fracture system. A network of primary, or higher transmissivity, fractures appeared to be providing a sufficient supply of water for the secondary fractures intersected by the borehole. The transmissivity estimated for this borehole is, therefore, considered to be a lower limit for the aquifer. 


\section{Borehole Storage}

The time at which borehole storage was assumed to be negligible was calculated using equation 1 . Aquifer tests 6,8 , and 9 were conducted at virtually the same discharge rate $(1.3 \mathrm{~L} / \mathrm{s})$ and with the same borehole and pump configuration. Borehole storage effects should, therefore, be negligible at the same time for each of the three tests. Using an assumed borehole diameter of $250 \mathrm{~mm}$ and a pump column pipe outside diameter of $95 \mathrm{~mm}$, borehole storage should be negligible after about 130 minutes of pumping.

\section{Test 6, August 22-24, 1995}

Transmissivity and specific-capacity estimates are provided for test 6 . Drawdown data were analyzed using the straight-line and the ASTM methods. Straight-line analysis for test 6 is presented in figure 6 . Pumping during test 6 lasted 48 hours at a mean discharge rate of $1.29 \mathrm{~L} / \mathrm{s}$. As previously mentioned, borehole storage effects are present during the first 130 minutes of pumping. Using conservative estimates of transmissivity ( $5 \mathrm{~m}^{2} /$ day) and specific yield (0.1), $u$ was calculated to be less than 0.01 after 20 minutes of pumping. To satisfy the solution requirement that $u$ be less than 0.01 and that borehole storage effects be negligible, the straight line was only fit to drawdown data after 130 minutes of pumping. A transmissivity of $6.0 \mathrm{~m}^{2} /$ day was determined for the drawdown portion of the test with the straight-line analysis.

The ASTM method was also used to determine transmissivity based on specific capacity. Neglecting the cyclic nature of the drawdown data and assuming a straight drawdown trend, a specific capacity of $6 \mathrm{~m}^{2} / \mathrm{d}$ was determined after 24 hours of pumping (table 7). A transmissivity of $5 \mathrm{~m}^{2} /$ day was calculated from the 24-hour specific capacity values (table 8). A specific yield of 0.01 was used in the calculation of $u$ for the ASTM method.

Table 7. Summary of specific-capacity values determined for aquifer tests 6,8 , and 9 in borehole UE-25 WT\#12

$[--$, no data $]$

\begin{tabular}{cccc}
\hline $\begin{array}{c}\text { Test } \\
\text { number }\end{array}$ & $\begin{array}{c}\text { Mean } \\
\text { discharge } \\
\text { (liters/second) }\end{array}$ & $\begin{array}{c}\text { Drawdown } \\
\text { after 24-hours } \\
\text { (meters) }\end{array}$ & $\begin{array}{c}\text { 24-hour } \\
\text { speclfic } \\
\text { capacity } \\
\text { (meters }{ }^{2} \text { day) }\end{array}$ \\
\hline 6 & 1.29 & 18.1 & 6 \\
8 & 1.27 & 14.9 & 7 \\
9 & 1.27 & 14.7 & 7 \\
Mean & -- & -- & 7 \\
\hline
\end{tabular}

Recovery data were dominated by boreholestorage effects, which resulted in virtually no analyzable data (fig. 10). Borehole storage appeared to be present during approximately the first 22 minutes of recovery. After borehole-storage effects were insignificant, there was less than $0.02 \mathrm{~m}$ of residualdrawdown data for analysis. Although this residual drawdown is considered real, the analysis would be based on such a small portion of the aquifer that the results would be meaningless. The recovery response is a function of the aquifer and borehole conditions and not because of equipment failure. Therefore, transmissivity is not determined from the recovery data.

Table 8. Summary of transmissivity values determined for aquifer tests 6,8 , and 9 in borehole UE-25 WT\#12

[--, no data; ASTM, American Society for Testing Materials]

\begin{tabular}{ccclc}
\hline Test number & Dates & $\begin{array}{c}\text { Data } \\
\text { analyzed }\end{array}$ & $\begin{array}{c}\text { Method of } \\
\text { analysis }\end{array}$ & $\begin{array}{c}\text { Transmissivity } \\
\text { (meters }\end{array}$ /day) \\
\hline 6 & $8 / 22-24 / 95$ & Drawdown & Straight-line & 6 \\
& & & ASTM & 5 \\
8 & $9 / 5-11 / 95$ & \multirow{2}{*}{ Drawdown } & Straight-line & 6 \\
& & & ASTM & 6 \\
9 & \multirow{2}{*}{$9 / 11-15 / 95$} & \multirow{2}{*}{ Drawdown } & Straight-line & 10 \\
& & & ASTM & 7 \\
Mean & -- & -- & -- & 7 \\
\hline
\end{tabular}




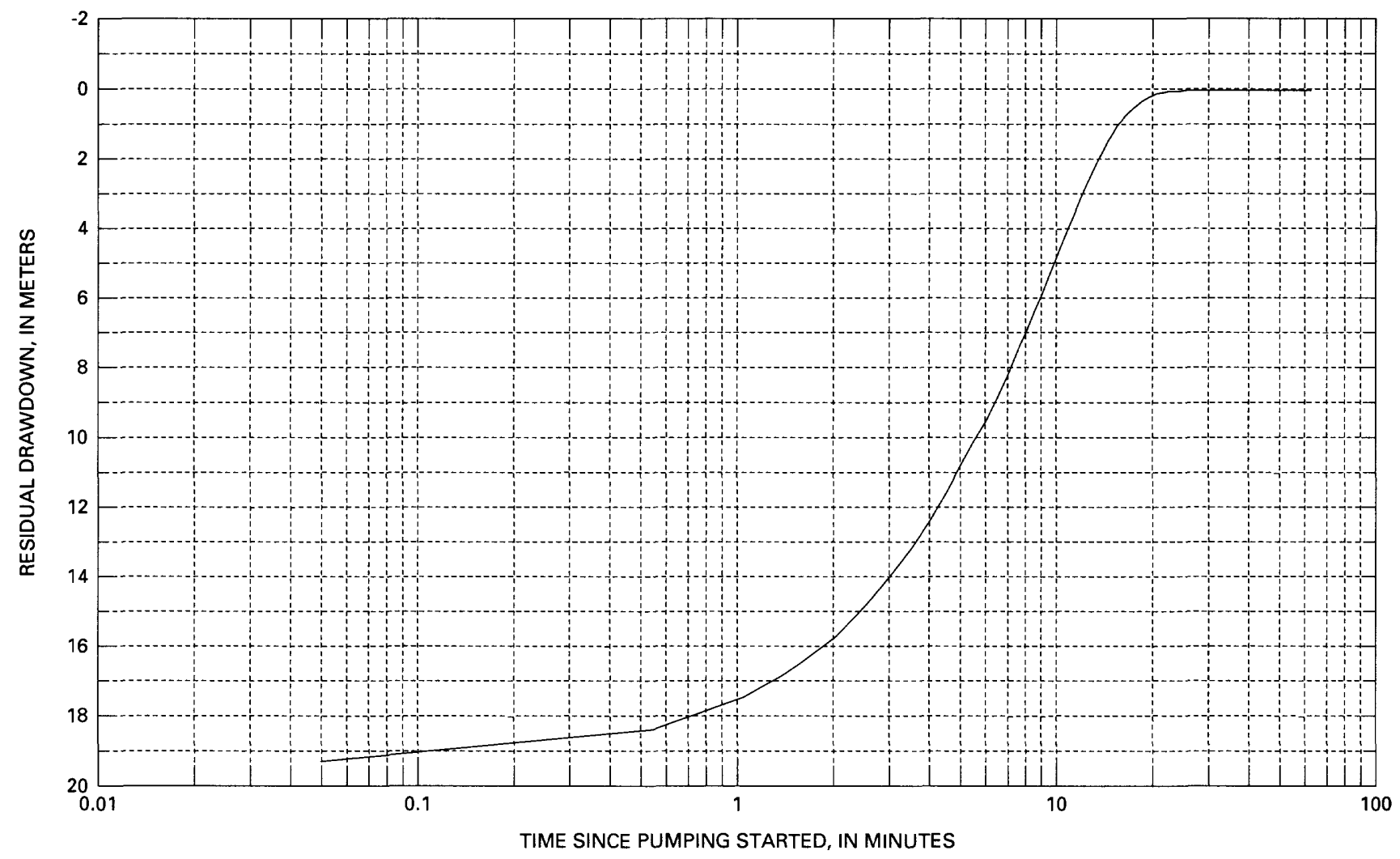

Figure 10. Recovery of residual drawdown as a function of time for aquifer test 6 , August 24, 1995, in borehole UE-25 WT\#12.

Test 8, September 5-11, 1995

Pumping during test 8 was conducted for 151.8 hours, at a mean discharge rate of $1.27 \mathrm{~L} / \mathrm{s}$, which was the longest continuous period of pumping in borehole UE-25 WT\#12. Borehole storage was negligible after the first 130 minutes of pumping. A decrease in slope occurs between 100 and 300 minutes and may indicate a delayed-yield response. To satisfy the criteria that $u$ is less than 0.01 and that delayed yield effects are minimized, the straight-line analysis is used only on drawdown data after 300 minutes. The straight-line analysis resulted in a transmissivity of $6.0 \mathrm{~m}^{2} /$ day (fig. 7 ).

The ASTM method was used to estimate transmissivity based on the borehole specific capacity. A specific capacity of $7 \mathrm{~m}^{2}$ /day was determined after 24 hours of pumping (table 7) and resulted in a transmissivity of $6 \mathrm{~m}^{2}$ /day (table 8 ).

Test 9, September 11-19, 1995

Test 9 was started approximately 75 minutes after the main generator failed and ended the drawdown portion of test 8. Pumping during test 9 lasted 93 hours at a mean discharge rate of $1.27 \mathrm{~L} / \mathrm{s}$. The first 130 minutes of pumping was determined to be influenced by the effects of borehole storage. A spike in the drawdown data at about 2,100 minutes was due to a decrease in discharge caused by a discharge line valve being inadvertently closed.

The drawdown data and straight-line analysis are included in figure 8. The straight-line segment between 60 and 2,000 minutes has an apparent transmissivity of $10.5 \mathrm{~m}^{2} /$ day. After 2,000 minutes, there is a slight break in slope with a resulting transmissivity of $8.6 \mathrm{~m}^{2} /$ day. This difference in transmissivity is not significant given the borehole sensitivity to discharge fluctuations. A transmissivity of $10 \mathrm{~m}^{2} /$ day is considered representative of the drawdown data for test 9 . The ASTM method resulted in a transmissivity estimate of $7 \mathrm{~m}^{2} /$ day.

As seen in test 6, the recovery data were dominated by borehole-storage effects, which resulted in virtually no analyzable data. Borehole-storage effects were interpreted as the first 22 minutes of recovery, leaving only about $0.02 \mathrm{~m}$ of residual drawdown data to analyze (fig. 11). The recovery 


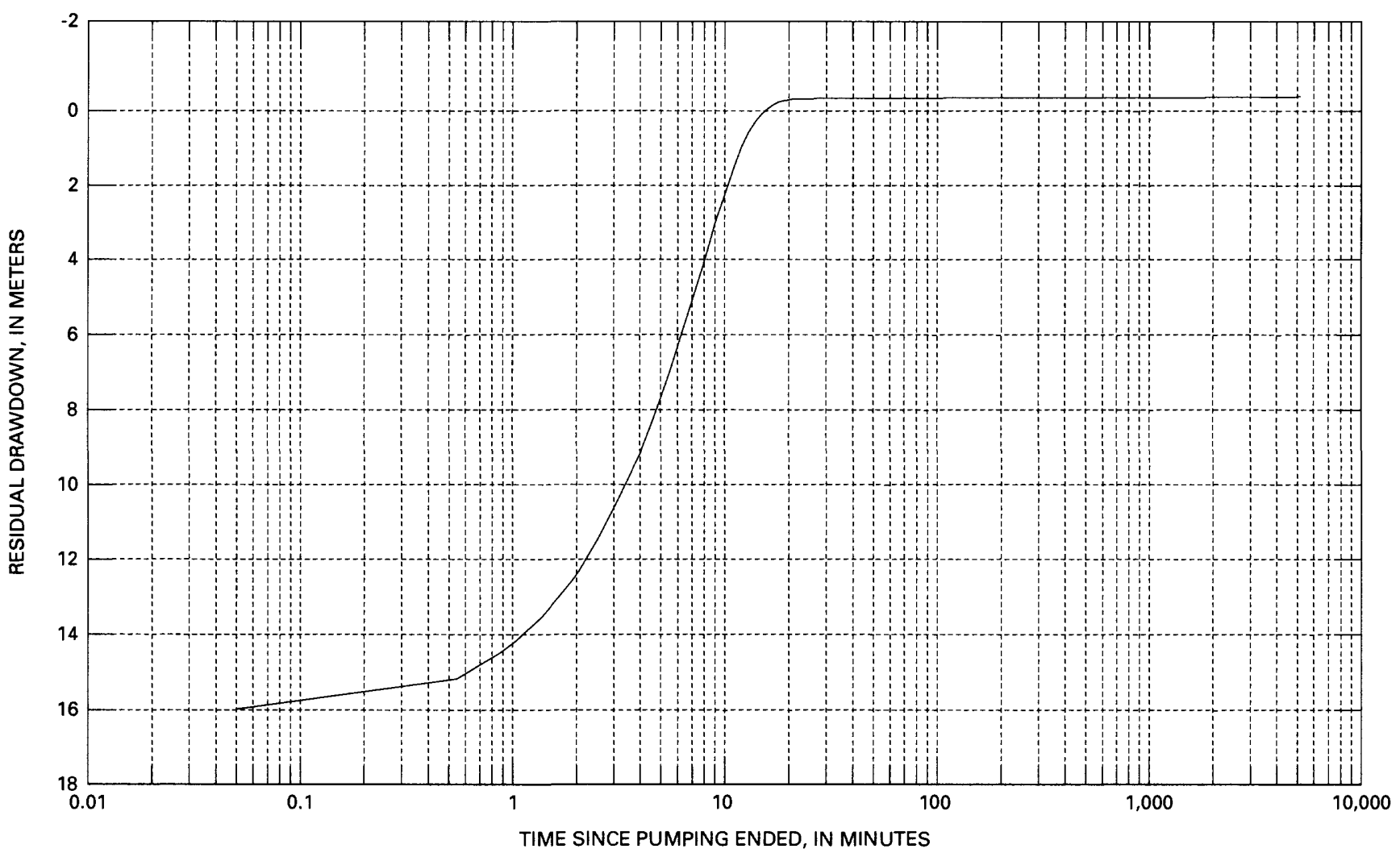

Figure 11. Recovery of residual drawdown as a function of time for aquifer test 9 , September $15-19,1995$, in borehole UE-25 WT\#12.

response is virtually the same as obtained during test 6 and is not a result of backflow of water from the discharge line. Determination of transmissivity based on these recovery data is considered unreliable, so no analysis is presented.

\section{Summary of Results}

Well losses and borehole-storage effects dominated the aquifer tests in borehole UE-25 WT\#12. The drawdown in the borehole appears not to be representative of the cone of depression around the borehole during pumping. Rapid return to prepumping water levels during recovery prevented determination of transmissivity based on the residualdrawdown data. A summary of the transmissivity values determined from the drawdown tests in borehole UE-25 WT\#12 is provided in table 8.

All of the analysis indicate that the transmissivity is relatively low and is probably a lower limit for the Topopah Spring Tuff. The best estimate of transmissivity at this borehole, given the conditions during aquifer testing, is the overall mean of $7 \mathrm{~m}^{2} /$ day.
Aquifer testing in the Topopah Spring Tuff has been completed in several boreholes and wells in the Yucca Mountain area. As previously discussed in this report, borehole USW WT-10 has an estimated transmissivity of $1,600 \mathrm{~m}^{2} /$ day. The Topopah Spring Tuff in well $\mathrm{J}-13$ has a reported transmissivity of $120 \mathrm{~m}^{2} /$ day (Thordarson, 1983, p. 27), and in well JF-3, the transmissivity is reported to be 13,000 to $14,900 \mathrm{~m}^{2}$ / day (Plume and La Camera, 1996, p. 17). Aquifer testing of the Topopah Spring Tuff and Bullfrog Tuff in well USW VH-1 resulted in transmissivity estimates of 450 to $2,200 \mathrm{~m}^{2} /$ day (Thordarson and Howells, 1987). Transmissivity estimates ranging from 840 to $6,000 \mathrm{~m}^{2} /$ day were obtained for the Topopah Spring Tuff in wells J-12 and J-13 (Young, 1972). These results indicate that transmissivity is highly variable in the Topopah Spring Tuff at Yucca Mountain. Transmissivity in borehole UE-25 WT\#12 is two to four orders of magnitude less than estimates obtained at other sites in the Yucca Mountain area.

An alternative interpretation of the results is that the transmissivity determined during aquifer testing in borehole UE-25 WT\#12 represents the penetrated 
section of the Calico Hills Formation and not that of the Topopah Spring Tuff. Data are not available to determine what portion of the borehole was producing water during pumping. Therefore, definitively determining what formation was effectively tested is not possible. The Calico Hills Formation typically has much lower transmissivity than the Topopah Spring Tuff, so it generally is more likely that waterproducing fractures would be found in Topopah Spring Tuff sections of the borehole. The transmissivity of $7 \mathrm{~m}^{2} /$ day is comparable to the transmissivity previously determined for the Calico Hills Formation by Thordarson (1983) and in borehole USW SD-7.

The degree of fracturing present in the boreholes is probably a controlling factor in the transmissivity at the sites. A significant difference between borehole UE-25 WT\#12 and the other wells is that there is only $41 \mathrm{~m}$ of saturated Topopah Spring Tuff, whereas $83 \mathrm{~m}$ of saturated Topopah Spring Tuff are present in USW WT-10 and significantly longer sections in the other wells. The chance of intersecting transmissive fractures appears to increase with increasing penetration through the Topopah Spring Tuff. Although borehole UE-25 WT\#12 penetrates the entire Topopah Spring Tuff, the water level is near the bottom of the section, which reduces the possibility of transmissive fractures being saturated and contributing water to the hole. It seems that only secondary fractures were producing water during pumping in borehole UE-25 WT\#12, and they could not transmit enough water to create a significant cone of depression. In contrast, borehole USW WT-10 seems to have intersected primary fractures that were capable of producing more water than could be discharged with the available pump.

\section{Borehole USW SD-7}

\section{Background}

Borehole USW SD-7 is located on the eastern slope of Yucca Mountain near the crest (fig. 1). Water was found during drilling at a depth of approximately $488 \mathrm{~m}$ in the bedded tuff near the base of the Calico Hills Formation. This depth is $4.5 \mathrm{~m}$ above the upper contact of the non- to partially welded Prow Pass Tuff. The water level rose $8.4 \mathrm{~m}$ in the borehole, and drilling operations were suspended until aquifer testing could be completed.

The aquifer testing in this borehole was unique in that it was conducted in units that are about $150 \mathrm{~m}$ above the regional water table. In March 1995, several aquifer tests of a few hours in duration and one 30-hour aquifer test were completed. In an effort to determine what was causing the water to perch and to increase the available drawdown for future testing, the borehole was cored an additional $9.1 \mathrm{~m}$ prior to the August 1995 aquifer tests. The origin of the water and mechanism(s) that created the perched-water body are beyond the scope of this report.

In August 1995, additional aquifer tests were conducted that verified the results obtained during March and provided more information that was helpful in understanding the perched-water system. When testing was completed in August, drilling operations resumed, and the borehole was completed at a total depth of $815 \mathrm{~m}$. Water-level measurements after completion of the borehole, by the drilling contractor, indicated that the water was at a level consistent with the regional water table. The borehole configuration at the time of the March and August tests is presented in table 9 .

Table 9. Summary of borehole USW SD-7 configuration during the March and August 1995 aquifer tests

\begin{tabular}{ccccccc}
\hline $\begin{array}{c}\text { Borehole location } \\
\text { (latltude } \\
\text { longltude) }\end{array}$ & Dates & $\begin{array}{c}\text { Total } \\
\text { depth } \\
\text { (meters) }\end{array}$ & $\begin{array}{c}\text { Drilledhole } \\
\text { dlameter } \\
\text { (meters) }\end{array}$ & $\begin{array}{c}\text { Interval } \\
\text { tested } \\
\text { (meters) }\end{array}$ & $\begin{array}{c}\text { Interval } \\
\text { thickness } \\
\text { (meters) }\end{array}$ & Formatlons tested \\
\hline $\begin{array}{r}36^{\circ} 50^{\prime} 06^{\prime \prime} \mathrm{N} \\
116^{\circ} 27^{\prime} 27^{\prime \prime} \mathrm{W}\end{array}$ & $3 / 13-27 / 95$ & 488 & 0.123 & $480-488$ & 8 & Calico Hills Formation \\
$36^{\circ} 50^{\prime} 06^{\prime \prime} \mathrm{N}$ & $8 / 7-24 / 95$ & 497 & 0.123 & $481-497$ & 16 & $\begin{array}{c}\text { Calico Hills Formation (12 m) } \\
116^{\circ} 27^{\prime} 27^{\prime \prime} \mathrm{W}\end{array}$ \\
\hline
\end{tabular}

Top of interval is the water surface at start of pumping; bottom of interval is total depth. 
The following is a brief geologic description of the borehole (M. Pitterle, written commun., 1996) [(Composite borehole log, Drilling Support Section, Drilling Support and Sample Management Dept., Technical and Management Support Services; 01/04/96)]:

Calico Hills Formation, bedded tuff: (477.7$488.3 \mathrm{~m}$ ) Tuff, alternating air fall/bedded and ashflow units: light brown, light-olive-gray, grayish-yellow brown, and yellowish-gray, nonwelded, vitric; $15-45$ percent pumice, decreasing with depth, very pale-orange to moderate orange to grayish-yellow, $2 \mathrm{~mm}$ or less; 5-10 percent phenocrysts of sanidine and oxidized biotite; 0-20 percent lithics, reddish-brown, $2 \mathrm{~mm}$ or less; ashfall/bedded units are typically very fine grained, locally graded; lithic swarms up to $0.12 \mathrm{~m}$ thick common, and one is present immediately above the lower contact; basal contact is sharp.

(488.3-492.9 m) Tuff, bedded/air fall: very pale orange to grayish-orange grading to pale brown and pale yellowish-brown, non- to partially welded, devitrified; 2-20 percent pumice, white, pale yellow and pale greenish-yellow, mostly 3-5 mm, up to $10 \times 10 \mathrm{~mm}$, locally altered to clay; 5-10 percent phenocrysts of sanidine, quartz and biotite; 5-8 percent lithic fragments, moderate brown, brownish-gray, moderate reddish-brown and very dusky red, subrounded to angular, $5 \times 5$ $\mathrm{mm}$; interval is thinly bedded, $0.03-0.30 \mathrm{~m}$ beds.

Prow Pass Tuff (492.9-496.2 m) Tuff, ashflow: grayish-orange, non- to partially welded, devitrified; 5 percent pumice, mostly to completely altered to pale yellow clay minerals, $10 \times 20 \mathrm{~mm}$; 5-10 percent phenocrysts of quartz, sanidine, biotite, and minor pyroxene; $2-5$ percent lithic fragments, very dusky red to blackish-red, angular, $5 \times 5 \mathrm{~mm}$.

(496.2-500.3 m) Tuff, ashflow: light brown, pale brown, and grayish-red, non- to partially welded, devitrified, locally silicified; 8-16 percent pumice, increasing with depth, light gray and pale orange, partially altered to pink and yellow clay minerals, flattening slight to none, mostly $2-10 \mathrm{~mm}$, up to $10 \times 15 \mathrm{~mm} ; 10$ percent phenocrysts of sanidine, plagioclase, minor quartz, and trace of magnetite coating on fracture surfaces; $<1$ percent lithic fragments, moderate reddish-brown, angular, mostly $2-3 \mathrm{~mm}$, up to $5 \mathrm{~mm}$.

There have been no previous hydrologic investigations at this borehole. The data and analysis presented in this report are the extent of available estimates of transmissivity in the tested interval.

\section{Aquifer Tests}

The March and August aquifer tests in borehole USW SD-7 were conducted with similar equipment and procedures. The major differences between the aquifer tests were that the borehole was deepened and that a lower discharge rate was used during the August tests. The resulting increase in the available drawdown and decrease in discharge rate allowed the August tests to be conducted for a longer period, which helped define the interval where water was entering the borehole.

Borehole development was needed prior to long-term aquifer testing because of drill cuttings remaining in the borehole. Dry-air drilling techniques were used for this borehole, which eliminated the need for adding drilling fluids to the borehole to remove cuttings. Drilling would proceed in cycles of coring followed by reaming the hole to a larger diameter. Water was initially found during a coring cycle and no reaming was attempted to clean the borehole of cuttings or to enlarge the borehole.

During initial pumping in March 1995, the water produced was muddy, indicating that cuttings caused by coring remained in the borehole. Several pumping periods were initiated prior to a 30 -hour aquifer test (test 4 ) to develop the borehole and to determine a sustainable pumping rate. Early pumping produced rapidly declining water levels followed by a reversal in which the water level in the borehole was rising while continuing to pump at a constant discharge rate. Subsequent pumping resulted in reproducible drawdown curves, which provided confidence that the borehole was sufficiently developed.

The lowest sustainable discharge rate that could be obtained with the pump used was $0.21 \mathrm{~L} / \mathrm{s}$. The lower the discharge rate, the longer a test could be conducted before drawing the water level down to the pump intake. The final test conducted during March, which was subsequently analyzed, was denoted as test 4. 
Following the conclusion of the March aquifer tests, the borehole was cored an additional $9.1 \mathrm{~m}$. Drilling operations were suspended after coring was completed, and aquifer tests were initiated in August 1995. Initial attempts to install a pressure transducer in the access tube were unsuccessful. The high fluid density in the access tube would not allow the transducer to move downward under its own weight. As a last alternative to enable testing to proceed, on August 4, 1995, drilling support personnel added water obtained from well $\mathrm{J}-13$ to the pump string, pumped water out of the hole, and then re-circulated the discharged water back down the access tube. Maintaining equal pumping and inflow rates was attempted, but the rates were not rigorously monitored. As a result of the recirculation of water, the access tube was sufficiently cleaned to allow installation and calibration of the pressure transducer.

Circulating water in the borehole could have impacted the water level and water chemistry. A detailed discussion of the potential impacts is beyond the scope of this report. It should be noted that the DTW measurements by the U.S. Geological Survey on August 1 and August 2, prior to circulation of water in the borehole, may have been affected by the high fluid density in the access tube. The two measurements had a difference in DTW of $0.34 \mathrm{~m}$ (table 10), which is large considering there were no human-induced changes on the system between the measurements. High fluid density may have prevented the steel tape from hanging straight in the access tube, which could result in erroneous measurements. A measurement on August 7, after circulation of the water, indicates that the water level was $0.36 \mathrm{~m}$ higher than on August 2 . The apparent rise in water level, however, may be due to measurement error caused by the high fluid density in the borehole on August 2, and not due solely to circulation of water in the borehole.

Precise determination of DTW in this borehole was critical to understanding the persistent dewatering that occurred because of pumping. A permanent decrease in water level following pumping provides information that is used to determine the extent of the water body being tested. Changes in water level from March 27 to August 1, provide information on the long-term recovery in the borehole. During removal of the pump string, following the completion of testing on March 27, the water standing in the discharge line was released into the borehole. The water that was put into the borehole contributed to the rise in water levels
Table 10. Depth-to-water measurements made with calibrated steel tapes, in borehole USW SD-7, between March 13 and August 24, 1995

\begin{tabular}{ccc}
\hline $\begin{array}{c}\text { Date of } \\
\text { measurement }\end{array}$ & $\begin{array}{c}\text { Total depth of borehole } \\
\text { (meters) }\end{array}$ & $\begin{array}{c}\text { Depth to water } \\
\text { (meters) }\end{array}$ \\
\hline $03 / 13 / 95$ & 488.3 & 479.95 \\
$03 / 27 / 95$ & 488.3 & 482.22 \\
$04 / 06 / 95$ & 488.3 & 481.70 \\
$04 / 13 / 95$ & 488.3 & 481.61 \\
$04 / 18 / 95$ & 488.3 & 481.63 \\
$04 / 24 / 95$ & 488.3 & 481.52 \\
$05 / 04 / 95$ & 488.3 & 481.38 \\
$05 / 11 / 95$ & 488.3 & 481.30 \\
$05 / 22 / 95$ & 488.3 & 481.25 \\
$08 / 01 / 95$ & 497.4 & 481.56 \\
$08 / 02 / 95$ & 497.4 & 481.22 \\
$08 / 07 / 95$ & 497.4 & 480.86 \\
$08 / 24 / 95$ & 497.4 & 1483.77 \\
\hline TEstimated based on locating the water surface with transducer
\end{tabular}

and calibrated transducer output.

between March 27 and April 6 (table 10). The persistent rise in water levels from March 27 to May 22 appears to be real and probably represents the longterm recovery of the system. Drilling operations between May 22, and August 1, may have altered the natural water level, but the effect of drilling activities on the system cannot be determined. A depth-to-water measurement with a calibrated steel tape was not possible at the conclusion of testing on August 24 because of an obstruction in the access tube. The DTW on August 24 was determined by locating the water surface with the transducer and verifying the level with the calibrated transducer output.

After the pressure transducer was installed for the August tests, the borehole was pumped for several periods to develop the borehole and to determine the most suitable discharge rate for a long-term test. The pump control used was mechanical and could only be set to discrete discharge rates. The most appropriate rate determined for the long-term test in August was $0.16 \mathrm{~L} / \mathrm{s}$. Repeatable drawdown curves were obtained, and the borehole appeared to be sufficiently developed. The test conducted from August 15-18, which was subsequently analyzed, was denoted as test 8 .

A progressive cavity pump was used during aquifer testing at USW SD-7. As previously discussed in early sections of this report, this type of pump can produce high-frequency water-level fluctuations in the 
borehole. Surging discharge is visibly evident when pumping at discharge rates less than about $0.3 \mathrm{~L} / \mathrm{s}$. Movement of the pump string could also cause waterlevel fluctuations. Unadjusted drawdown data, therefore, have high-frequency noise within the basic trend as illustrated in figures 12 and 13. Recovery data are smooth, as illustrated in figures 14 and 15 , which verifies that the noise in the drawdown data was pump induced.

\section{Analysis and Results}

The challenge of analyzing test data from borehole USW SD-7 primarily was due to the limited extent of the water body. Analytical solutions in ground-water hydrology typically assume that the aquifer is of infinite extent. Perched water clearly violates this assumption and could lead to serious errors in the analysis. In an attempt to minimize errors due to the limited reservoir, the analysis is restricted to the data obtained prior to the onset of boundary effects. It also appears that the permanent decrease in the volume of the reservoir because of pumping contributed to lower transmissivity estimates in the August test as compared to the March test.

The drawdown data obtained during August (test 8 ) indicate that additional water-producing fractures were not intersected during deepening of the borehole. The slope and shape of the linear drawdown curves, before and after deepening of the borehole, are very similar over the same pumping period (figs. 12 and 13). If the water-producing capacity of the borehole increased after coring, it would be expected that the rate of drawdown would have decreased during test 8. Although there is a slight decrease in slope of the linear drawdown curve for test 8 , this is attributed to the discharge rate being lower than in test 4.

\section{Borehole Storage}

The time at which borehole storage was assumed to be negligible was calculated with equation 1. Aquifer tests 4 and 8 were conducted at slightly different discharge rates $(0.21 \mathrm{~L} / \mathrm{s}$ and $0.16 \mathrm{~L} / \mathrm{s}$ ), but with the same borehole diameter and pump configuration. A borehole diameter of $127 \mathrm{~mm}$ and a pump column pipe outside diameter of $95 \mathrm{~mm}$ were used when determining borehole-storage effects for tests 4 and 8 . Borehole storage should be negligible after about 20 minutes of pumping during test 4 and after about 30 minutes during test 8 .

\section{Test 4, March 1995}

Test 4 consisted of 30 hours of pumping at a mean discharge rate of $0.21 \mathrm{~L} / \mathrm{s}$. Pumping was terminated when the drawdown reached the pump intake. The test was characterized by the rapid, initial drawdown attributed to borehole storage, followed by a linear decline in water levels (fig. 16). Transmissivity estimates were obtained from the drawdown data with the straight-line method and Rorabaugh's (1956) method. Specific capacity was estimated after 24 hours of pumping to allow comparison with the other boreholes in this report. The ASTM method was not used to estimate transmissivity because the boundary effects, due to the limited reservoir, were influencing the drawdown at relatively early pumping time. Any transmissivity estimates obtained with data after the onset of the boundary effects could be erroneous.

High frequency water-level fluctuations are present in the drawdown data (fig. 12) and are attributed to pump interference. In order to obtain a smoother curve for the analytical solutions, the drawdown data were digitally filtered. The data were originally collected at irregular time intervals, but digital filters should be applied only to regularly spaced data. The data were linearly interpolated at 5 -second intervals, between the existing data points to obtain a regularly spaced data set. A low-pass butterworth, order 4, digital filter with a cutoff frequency of 800 cycles per day was used to remove the highfrequency noise from the drawdown data. The filter cutoff-frequency for test 4 drawdown data is artificially low due to the interpolation of data points. The interpolation procedure often resulted in many data points being fit between two existing data points. There is essentially no fluctuation for the interpolated portions of the data set, which lowers the cutoff frequency required for the entire data set. The filtered data were sampled every 30 seconds to obtain a reasonably sized data set that honored the original data (fig. 12).

The straight-line method was used to analyze drawdown data in borehole USW SD-7. Determination of the appropriate data to fit the straight line is critical to obtaining a reasonable estimate of transmissivity. Three criteria must be met in the analysis, the 


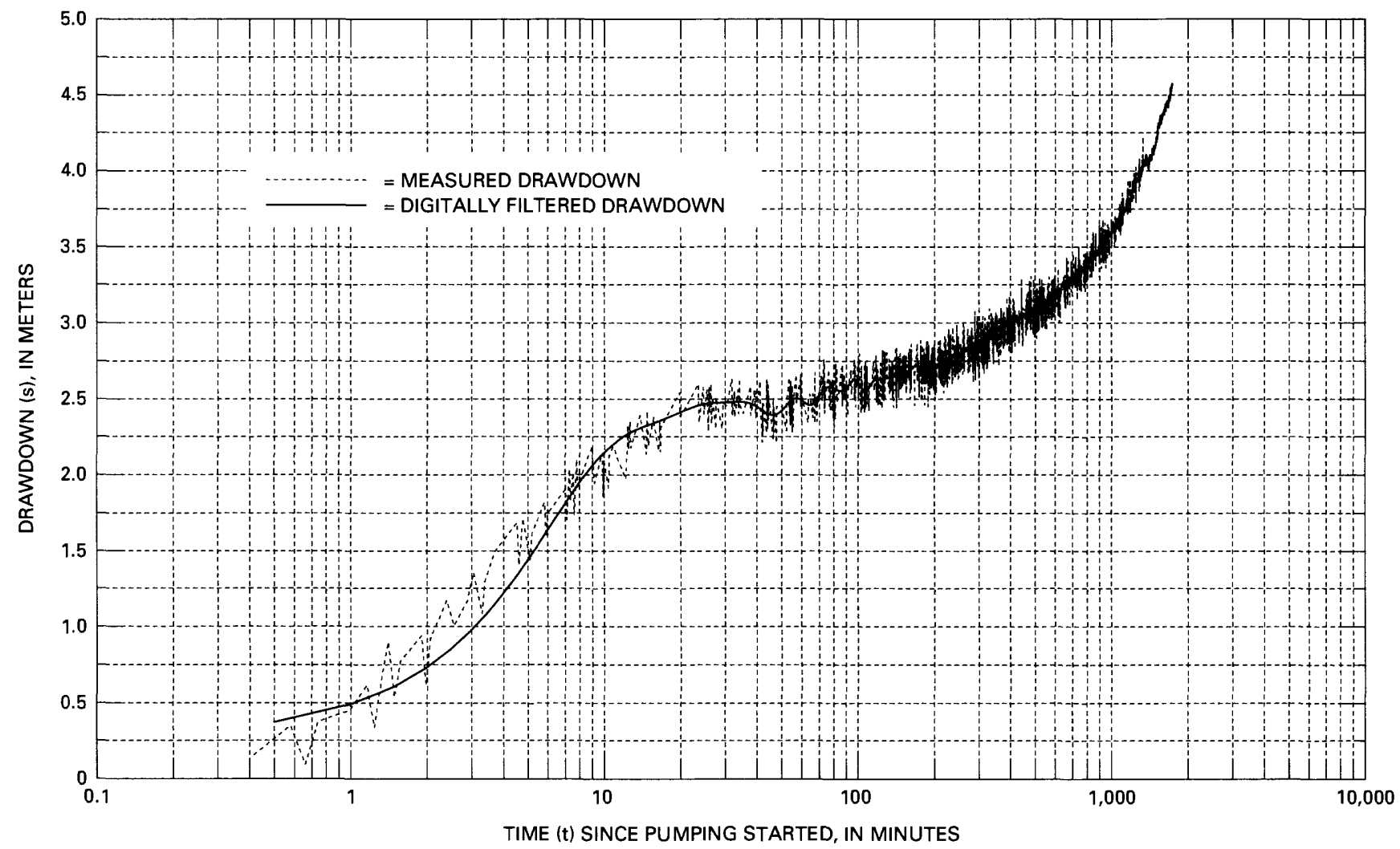

Figure 12. Measured drawdown and digitally filtered drawdown as a function of time during aquifer test 4, March 20-21, 1995, in borehole USW SD-7.

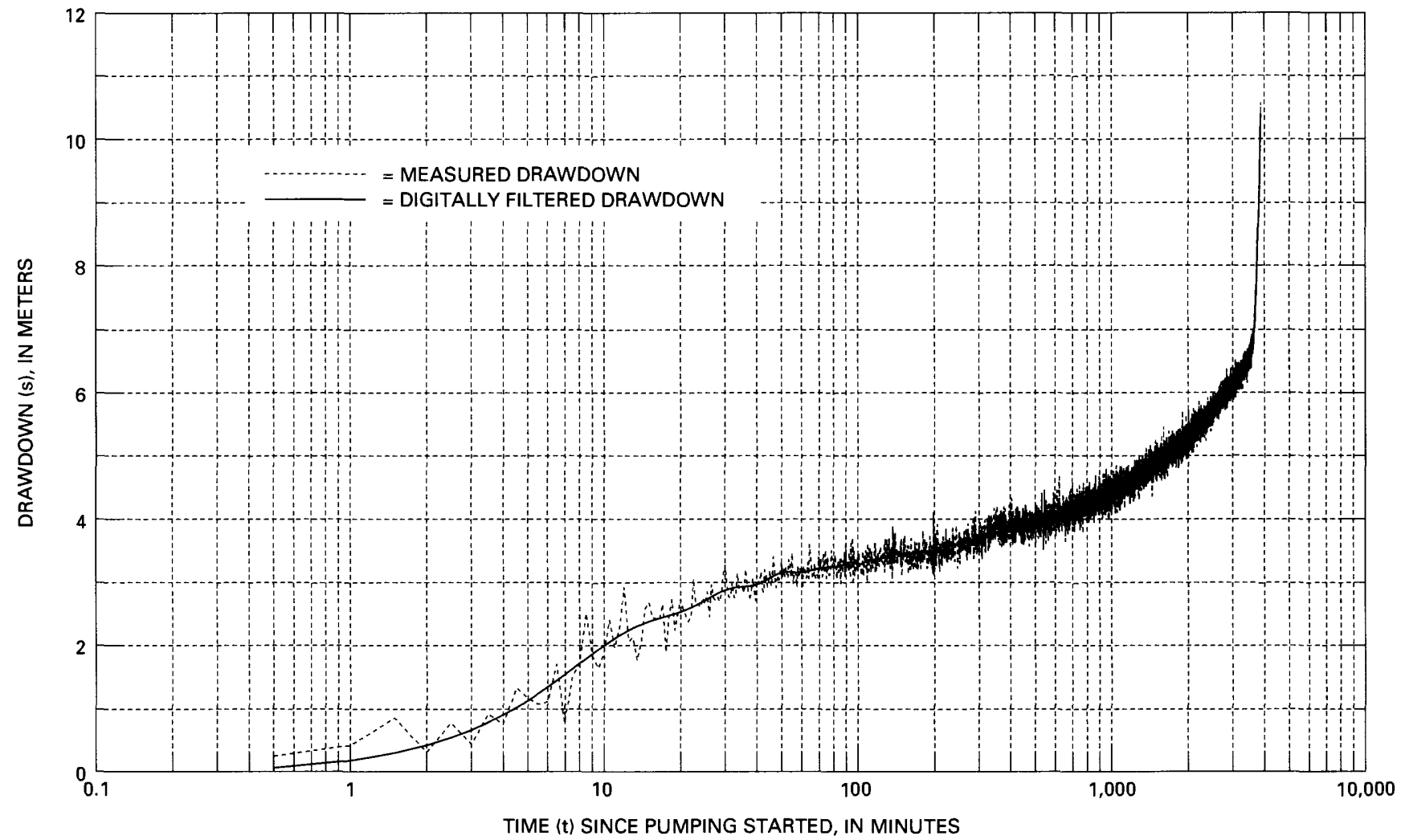

Figure 13. Measured drawdown and digitally filtered drawdown as a function of time during aquifer test 8 , August 15-18, 1995, in borehole USW SD-7. 


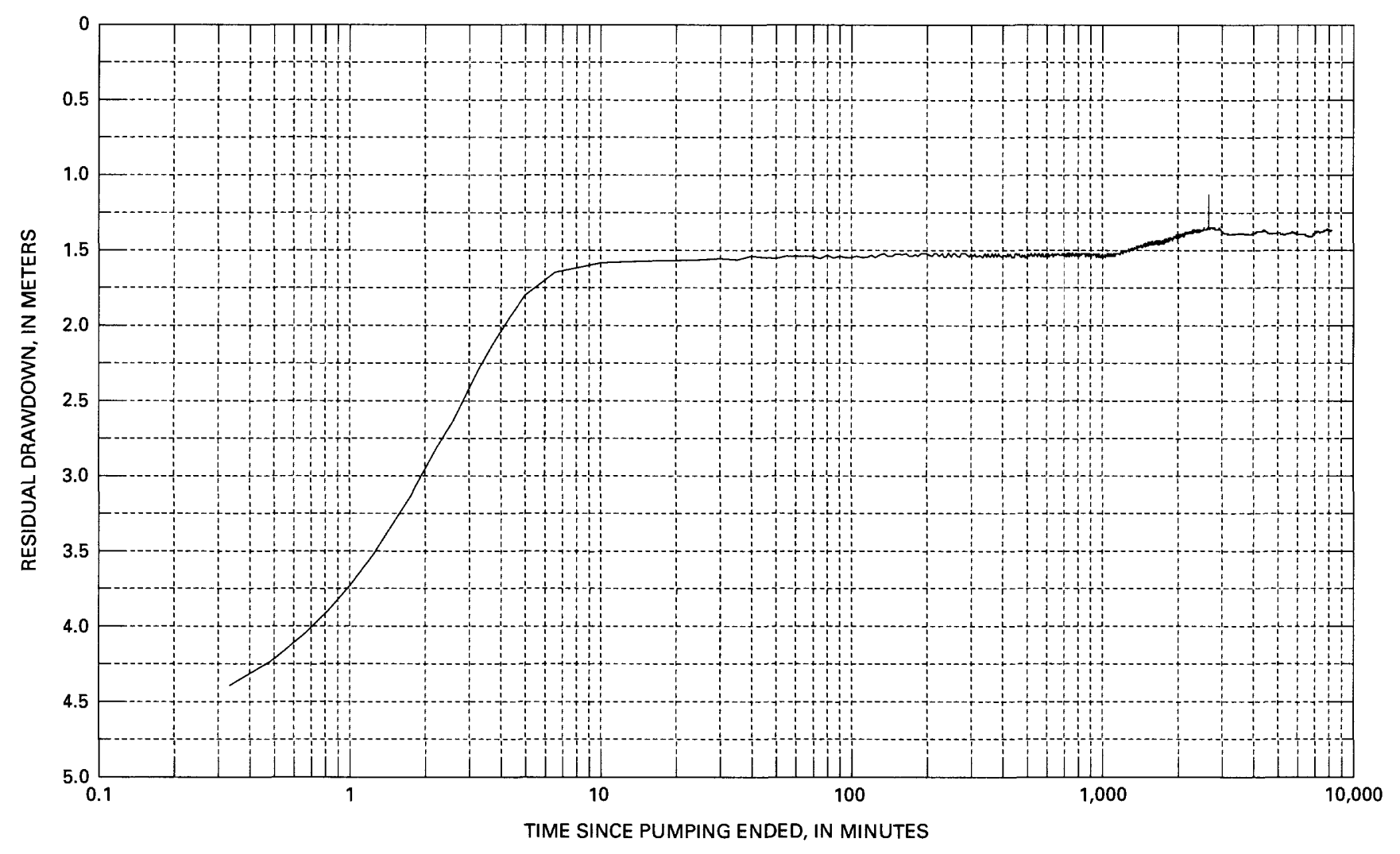

Figure 14. Recovery of residual drawdown as a function of time for aquifer test 4, March 21-27, 1995, in borehole USW SD-7.

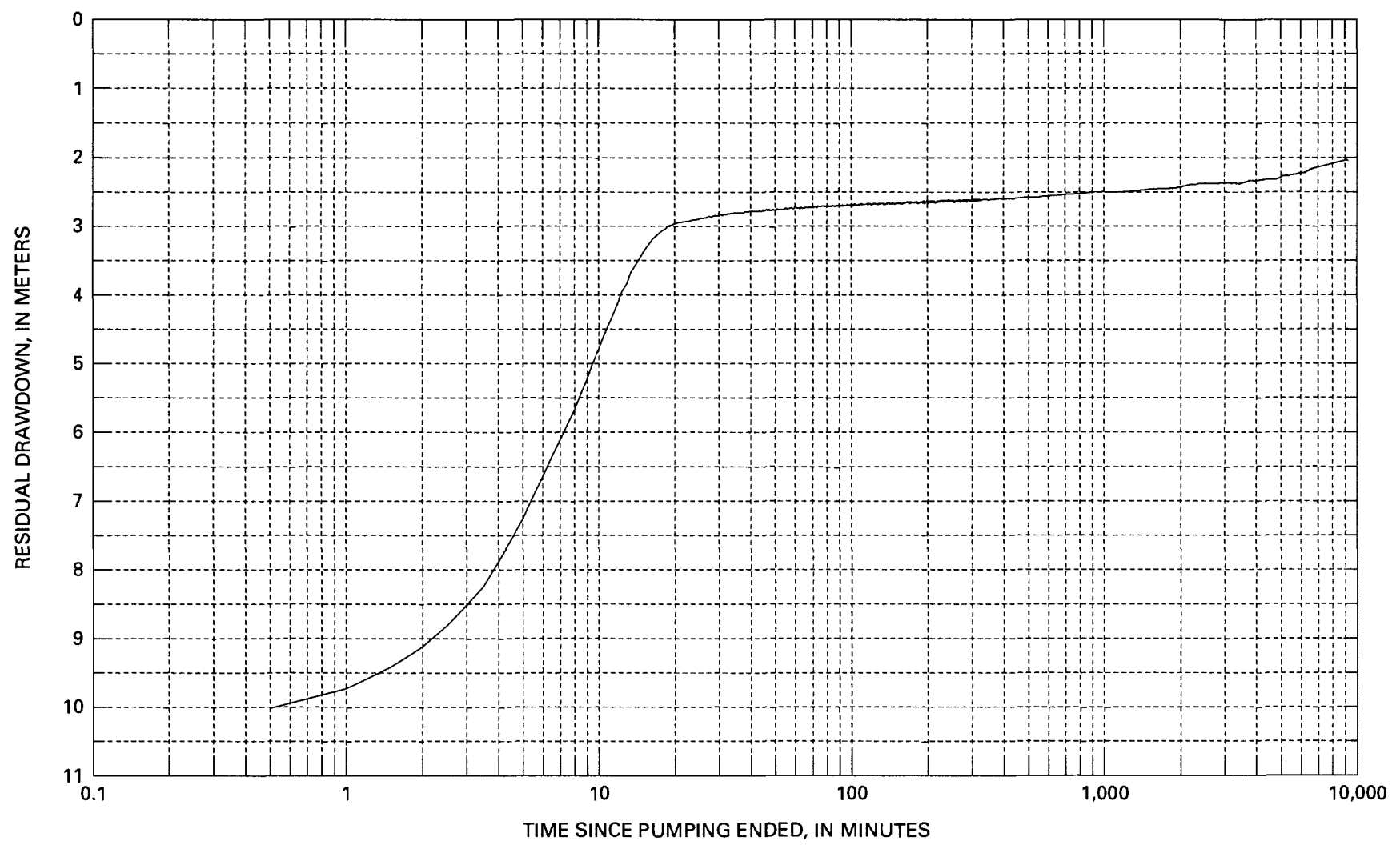

Figure 15. Recovery of residual drawdown as a function of time for aquifer test 8, August 18-24, 1995, in borehole USW SD-7. 


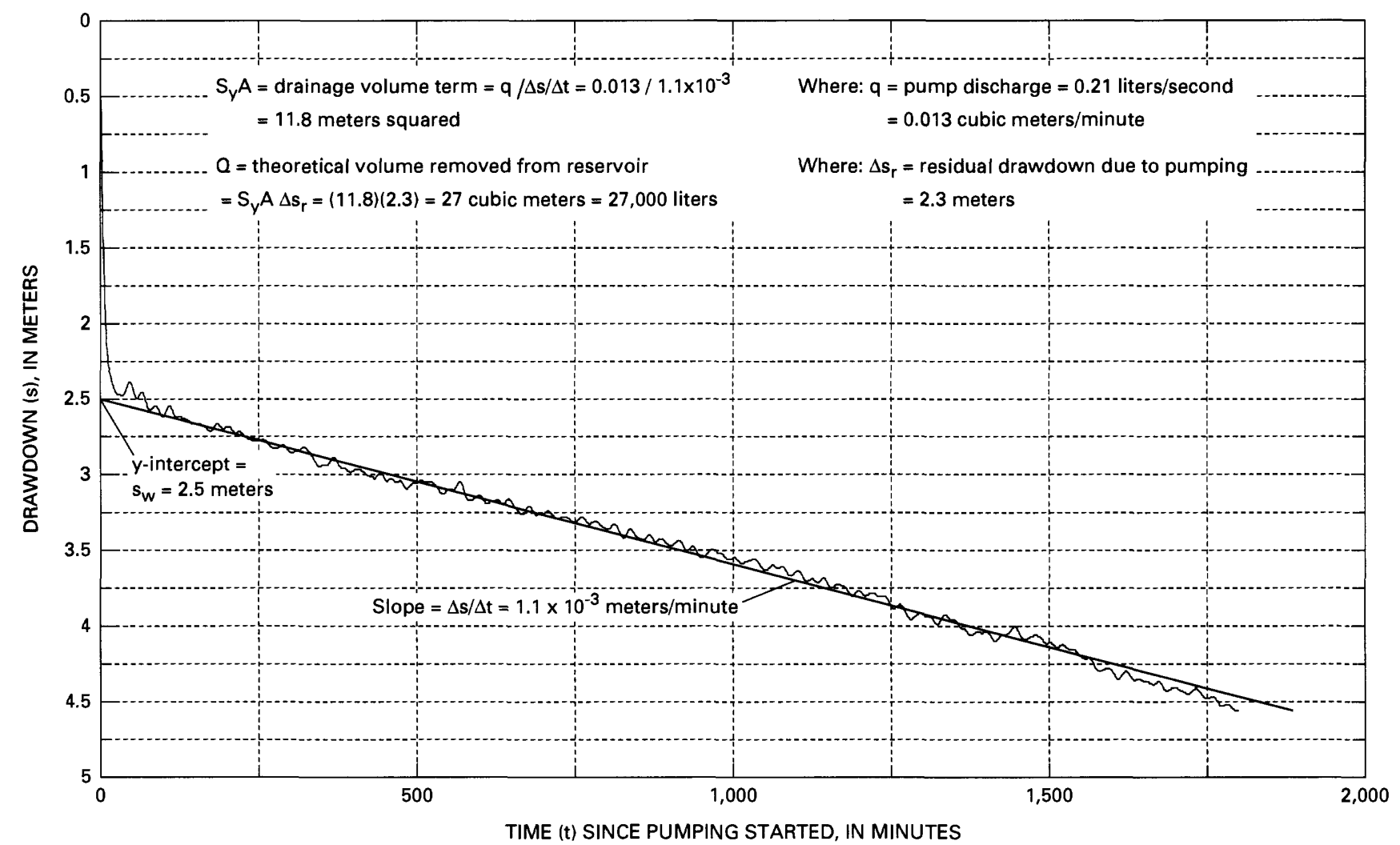

Figure 16. Digitally filtered drawdown data as a function of time and determination of aquifer characteristics used in the Rorabaugh method and reservoir-volume analysis for aquifer test 4, March 20-21, 1995, in borehole USW SD-7.

value of $u$ must be less than 0.01 , borehole-storage effects must be negligible, and boundary effects cannot be present. Assuming a transmissivity value of $5 \mathrm{~m}^{2} /$ day and a conservative specific yield of $0.1, u$ is less than 0.01 after 3 minutes of pumping. As previously mentioned, borehole-storage effects should be negligible after about 20 minutes of pumping. The straight line is fit to the linear portion of the drawdown curve that starts after the end of borehole-storage effects (fig. 17). The drawdown curve deviates from the straight line after about 70 minutes. Deviation from the straight line or a change in slope may indicate that a boundary has been reached by the cone of depression (Driscoll, 1986, p. 231). It is likely that the boundary of the reservoir has been reached and that dewatering is occurring, which limits the flow of water to the borehole. A transmissivity of $8 \mathrm{~m}^{2} /$ day was obtained from the straight-line fit to the data starting immediately after borehole storage was negligible until about 70 minutes after pumping started (fig. 17).

The Rorabaugh method was also used to determine transmissivity in borehole USW SD-7. The conceptual model of the flow system that is assumed for solving equation 6 is provided as figure 18 .
Details of the flow system concerning the perching mechanism or layer, distance to faults, and stratigraphy are beyond the scope of this report. The reservoir intersected by borehole USW SD-7 is assumed to be a thin (less than $1 \mathrm{~m}$ ) fractured zone that follows the bedding planes. The idealized model of the flow system assumes a 6-degree easterly dip for bedding (W.C. Day, U.S. Geological Survey, oral commun., 1996). A fault or other mechanism that is preventing the perched water from draining, is located down dip of the borehole. The distance to the reservoir boundary, $R_{e}$, is solved for trigonometrically with the height of water in the borehole (above the point at which water was observed during coring) and the dip of the bedding. The water body is assumed to be under water-table conditions at the point were the fracture zone becomes unsaturated. Under nonpumping conditions, the water in the borehole appears to be confined because of the water-level rise above the point of entry in the borehole. Once pumping has begun and sufficient drawdown in the borehole has occurred to impact the water level at the reservoir boundary $\left(\mathrm{s}_{\mathrm{w}}\right)$, water-table conditions and 


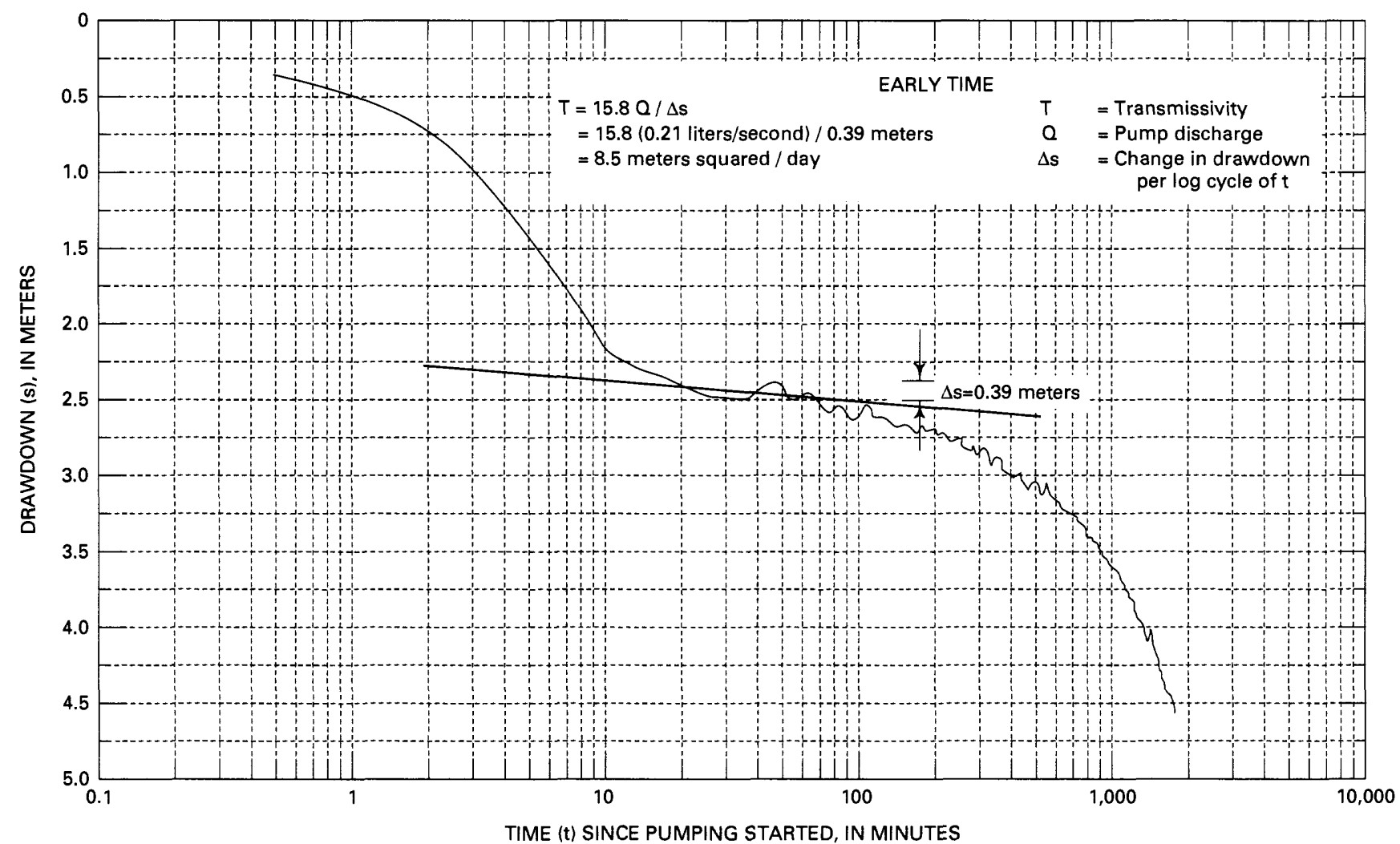

Figure 17. Aquifer-test analysis by straight-line analytical solution using digitally filtered drawdown data for test 4 , March 20-21, 1995, in borehole USW SD-7.

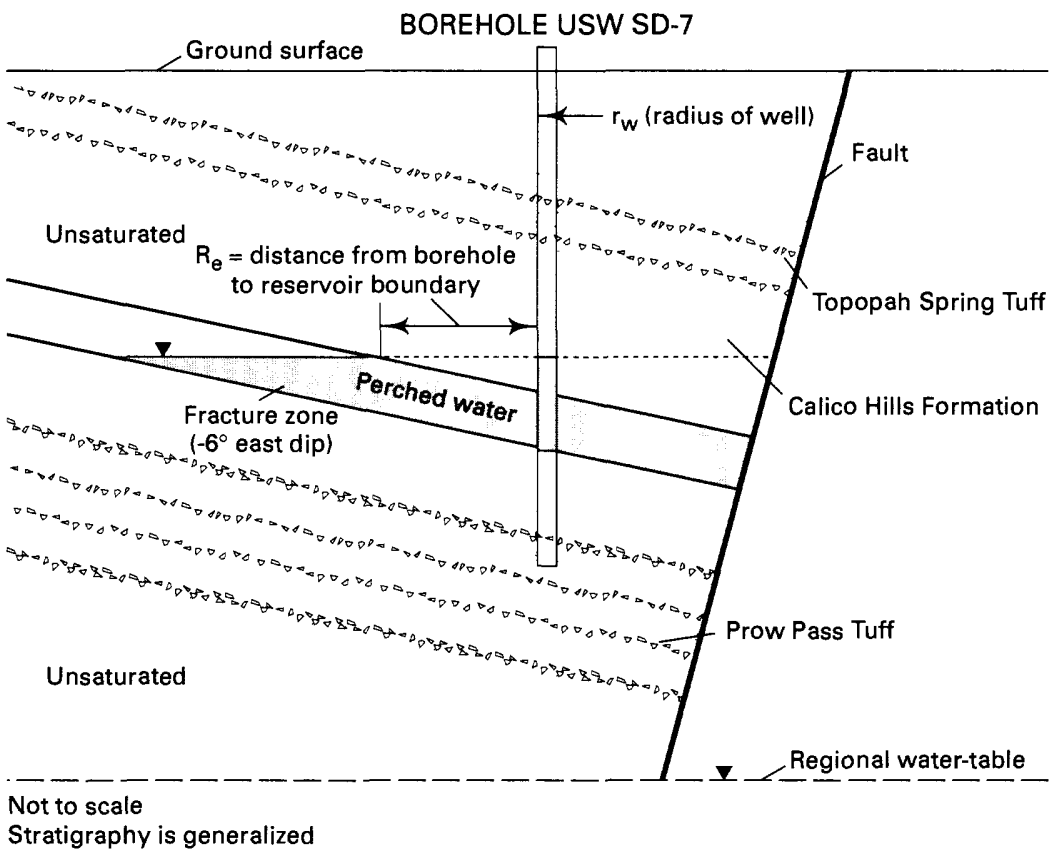

Figure 18. Idealized conceptual model of perched-water system intersected by borehole USW SD-7. Definition of variables used in the Rorabaugh method are also provided. 
drainage occur at the saturated outcrop of the reservoir.

Transmissivity was estimated to be $9 \mathrm{~m}^{2} /$ day with Rorabaugh's method (eq. 6) with the following values: distance to the reservoir boundary $\left(R_{e}\right)$ is $80 \mathrm{~m}\left(8.4 / \sin 6^{\circ}\right)$; radius of the borehole is $0.06 \mathrm{~m}$; discharge is $0.21 \mathrm{~L} / \mathrm{s}$; and the $y$-intercept $\left(\mathrm{s}_{\mathrm{w}}\right)$ is $2.5 \mathrm{~m}$ (fig. 19). Specific capacity after 24 hours of pumping is $4 \mathrm{~m}^{2}$ /day.

Analysis of recovery data is not presented because of the response being dominated by borehole storage (fig. 14). Rapid initial recovery is a function of the reservoir and borehole conditions and not because of backflow from the pump-discharge line. In borehole USW SD-7, fracture-flow conditions, limited extent of the reservoir, and residual drawdown resulted in recovery data that did not fit the general theory of ground-water flow. There appears to be slow recovery of the reservoir after the initial surge of water into the borehole (fig. 14). This slow recovery appears to have continued as indicated by DTW measurements after the March aquifer tests (fig. 20). A change in the slope of the recovery curve between 1,000 and 2,500 minutes and the spike at about 2,500 minutes is assumed to be due to instrument malfunction (fig. 14).

Pumping during March $(35,500 \mathrm{~L})$ resulted in $2.3 \mathrm{~m}$ of residual drawdown, based on the water-level measurements made on March 13 and March 27, 1995. Recovery of water levels between the March and August aquifer testing probably did not solely represent the system tested in borehole USW SD-7. Drainage from the dewatered portion of the reservoir probably would not continue to contribute water to recovery over a 4-month period. Another source of water may have been contributing to the observed slow recovery, and the hydraulic connection to the reservoir tested in borehole USW SD-7 was poor. The slow recovery of water levels after the March aquifer tests (fig. 20) may indicate that there is flow across low-permeability boundaries that separates the perched-water reservoir intercepted by borehole USW SD-7 and adjacent perched-water bodies. This interpretation implies that a much larger perchedwater system may exist in the vicinity of borehole USW SD-7.

\section{Test 8, August 1995}

A 64.6-hour aquifer test (test 8) was conducted in borehole USW SD-7 from August 15-18, 1995, at a mean discharge rate of $0.16 \mathrm{~L} / \mathrm{s}$. As a result of additional coring that increased the depth of the borehole, available drawdown during pumping was increased, over conditions during test 4 . The response to pumping was similar to the March 1995 testing with the exception that the water level was lowered below the apparent interval that was producing water. After about 3,600 minutes of pumping, the water level reached a borehole depth of $488 \mathrm{~m}$, and the rate of drawdown dramatically increased (figs. 19 and 21). The 488-m depth corresponds to the position where water was first observed during coring operations. The sudden change in slope indicates that this interval contained the primary water-producing fracture(s). As the water level was lowered below this producing interval, flow to the borehole was along a seepage face, and saturated flow conditions ceased to exist. The remaining available drawdown was rapidly exhausted, and pumping was terminated about 4 hours after reaching the fracture interval.

High frequency water-level fluctuations are present in the drawdown data (fig. 13) and are attributed to pump interference. To obtain a smoother curve for the analytical solutions, the drawdown data were digitally filtered. A low-pass butterworth, order 4, digital filter with a cutoff frequency of 5,000 cycles per day was used to remove the high-frequency noise from the drawdown data. During test 8 , data collection was at a higher, uniform-sampling rate than during test 4 , so test 8 data required a higher cutoff frequency than test 4 drawdown data. The filtered data set honors the original data and was used in the analysis (fig. 13).

Borehole-storage effects during test 8 were similar to test 4 but lasted slightly longer because of the lower pumping rate. As previously mentioned, borehole storage effects should be negligible after about 30 minutes of pumping.

Transmissivity was estimated with the straightline and Rorabaugh methods. The straight-line analysis resulted in a transmissivity of $4 \mathrm{~m}^{2} /$ day and is presented in figure 21. At about 300 minutes, the drawdown curve deviates from the straight line indicating that the reservoir boundary is affecting the response. The Rorabaugh method (eq. 6) resulted in a transmissivity of $5 \mathrm{~m}^{2} /$ day. The distance from the borehole to the reservoir boundary was solved trigonometrically with the height of the water column and dip of bedding $\left(R_{e}=7.4 / \tan 6=70 \mathrm{~m}\right)$. The $\mathrm{y}$-intercept of the linear drawdown plot $\left(\mathrm{s}_{\mathrm{w}}\right)$ is $3.5 \mathrm{~m}$ 


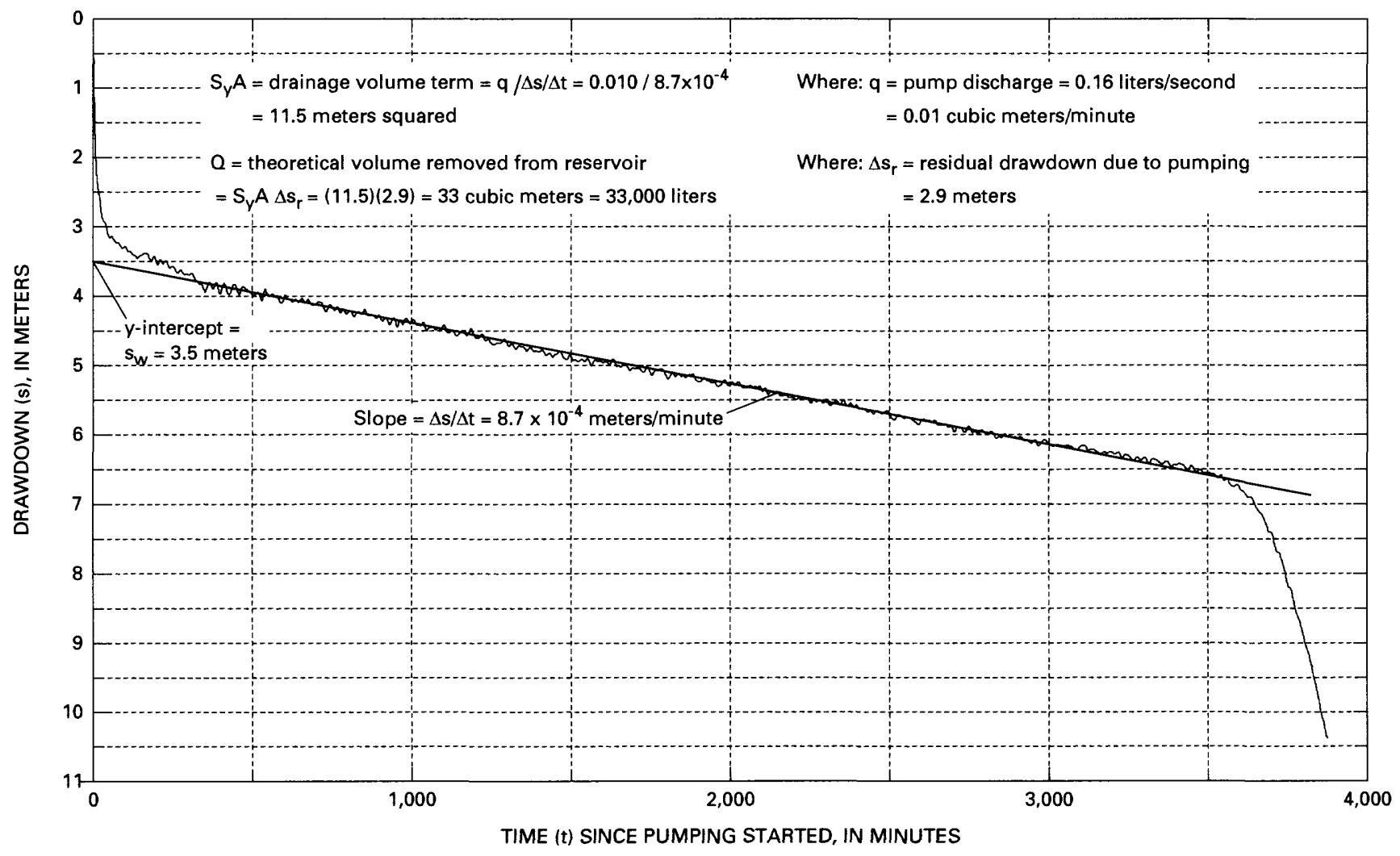

Figure 19. Digitally filtered drawdown data as a function of time and determination of aquifer characteristics used in the Rorabaugh method and reservoir-volume analysis for test 8 , August 11-15, 1995, in borehole USW SD-7.

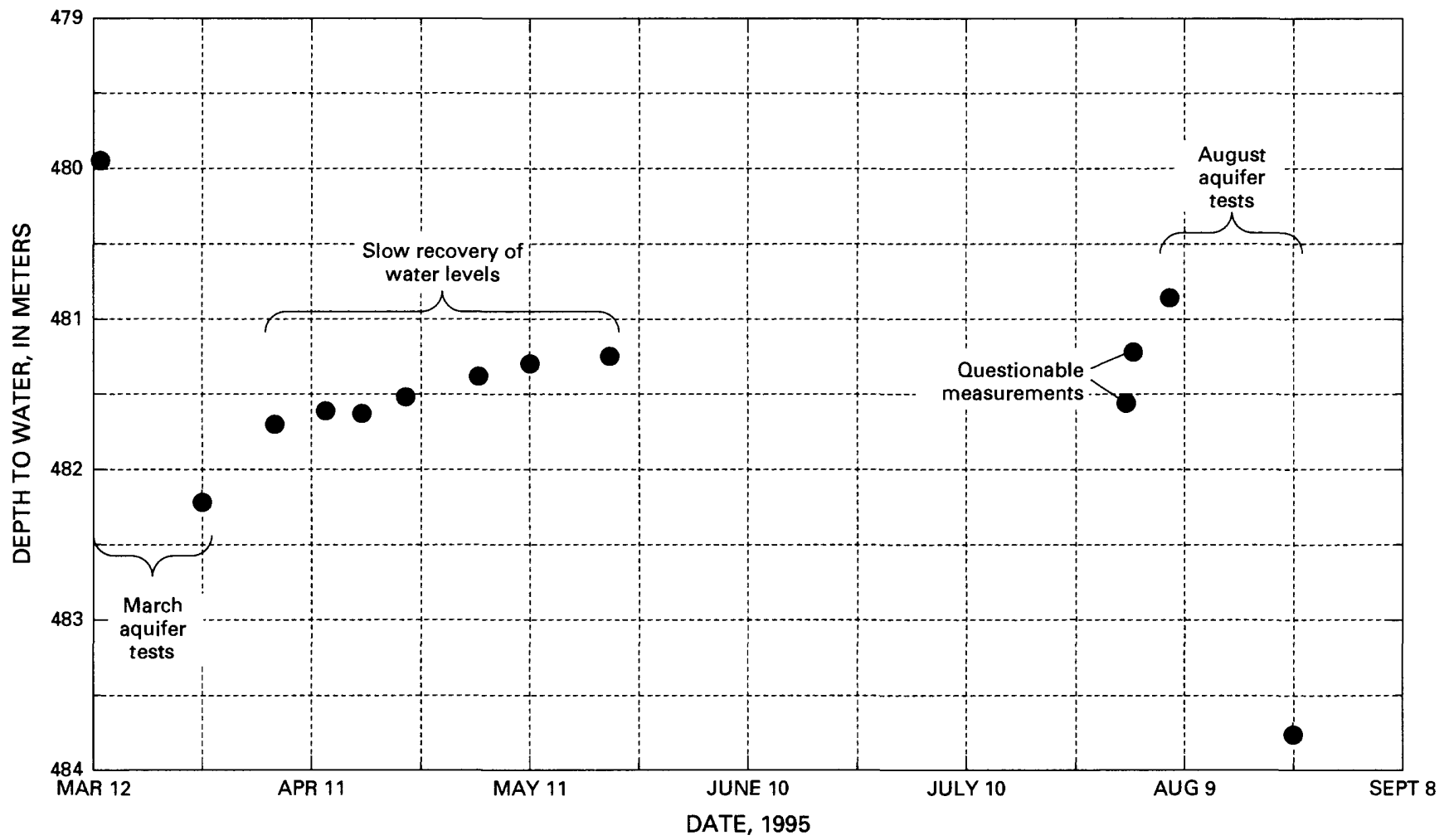

Figure 20. Steel-tape depth-to-water measurements in borehole USW SD-7, between March 13 and August 24, 1995. 


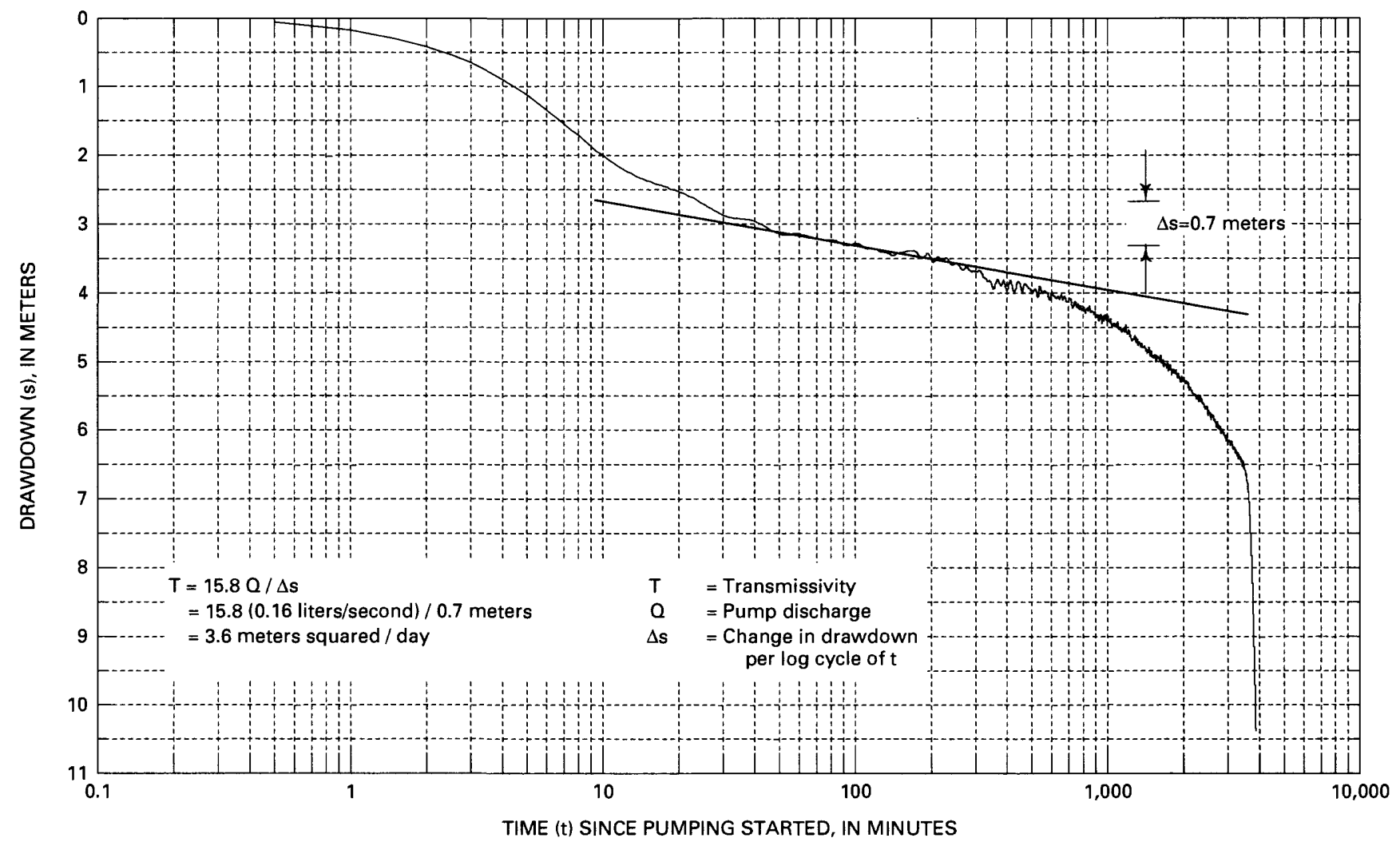

Figure 21. Aquifer-test analysis by straight-line analytical solution using digitally filtered drawdown data for test 8 , August 15-18, 1995, in borehole USW SD-7.

(fig. 19), and discharge (Q) is $0.16 \mathrm{~L} / \mathrm{s}$. Specific capacity after 24 hours of pumping is $3 \mathrm{~m}^{2} /$ day.

Recovery data for test 8 are similar to those obtained for test 4 and are not analyzed because of borehole-storage effects. As a result of pumping during August $(46,500 \mathrm{~L})$, there was $2.9 \mathrm{~m}$ of residual drawdown, based on DTW measurements on August 7 and August 24, 1995. Long-term recovery could not be monitored in this borehole because of resumption of drilling activities. The recovery data that were collected indicate that a slow recovery of water levels followed the initial surge of water into the borehole (fig. 15), similar to recovery following test 4 . In order to complete the borehole at the planned total depth, the perched-water zone was cased at the conclusion of aquifer testing, which prevents further monitoring of the reservoir.

\section{Reservoir Volume}

The volume of the water body intersected by borehole USW SD-7 was estimated with equations 7 and 8. Determination of the drainage term, $S_{y} A$, and the theoretical discharged volume $(\mathrm{Q})$ is presented on figures 16 and 19 for tests 4 and 8 . The theoretical discharged volume for test 4 is $27,000 \mathrm{~L}$, and the actual volume pumped was $23,000 \mathrm{~L}$; a difference of 17 percent. The theoretical discharged volume for test 8 is $33,000 \mathrm{~L}$, and the actual volume pumped was $37,000 \mathrm{~L}$; a difference of 11 percent. The theoretical estimates are close to the actual discharged volumes, which provides confidence that the method is appropriate and the $S_{y} A$ terms are valid. The mean of the drainage terms $\left(\mathrm{S}_{\mathrm{y}} \mathrm{A}\right)$ is 11.6, and it is used in the calculation of the total reservoir volume. Using equation 8 with the mean $\mathrm{S}_{\mathrm{y}} \mathrm{A}$ term and a height of the water column $\left(\mathrm{h}_{\mathrm{w}}\right)$ of $8.4 \mathrm{~m}$, the pre-pumping reservoir volume is $97,000 \mathrm{~L}$. When the reservoir volume calculation is repeated with $h_{w}$ equal to 7.4 , based on the apparent reservoir thickness at the start of the August tests, a volume of $86,000 \mathrm{~L}$ is obtained. If there was no long-term recovery in the reservoir, it would be expected that the reservoir-volume estimates would differ by the volume pumped during March testing. The volume estimates differ by $11,000 \mathrm{~L}$, but $35,500 \mathrm{~L}$ were pumped during March. This may 
indicate that long-term recovery is occurring, which is consistent with water-level measurements made during the summer of 1995 . A summary of the reservoir-volume estimates is provided in table 11 .

The reservoir-volume estimates are probably within 50 percent of the actual volume and are provided as rough estimates that may be useful in other studies at Yucca Mountain. The method used to calculate reservoir volume has not been used previously and has not been empirically verified. It should be noted that any water that exists in the down dip portion of the reservoir is not accounted for in the volume estimates.

\section{Summary of Results}

Transmissivity estimates for test 4 were nearly twice the estimates obtained for test 8 in borehole USW SD-7. Two analytical methods resulted in similar transmissivity estimates for each test. A summary of the transmissivity analysis is presented in table 12 . The difference in transmissivity estimates between tests could be because of violation of the analytical-solution assumptions or due to reservoir depletion. Residual drawdown due to pumping probably resulted in different hydraulic conditions for tests 4 and 8, which implies that the same reservoir was not tested during the March and August tests. The transmissivity estimates are probably valid only for the conditions at the time of aquifer testing. Transmissivity differences are relatively small, and a mean transmissivity of $6 \mathrm{~m}^{2} /$ day appears to be a reasonable estimate for this reservoir, based on the hydrologic conditions. Results from all tests and methods consistently indicate that the transmissivity in this borehole is relatively low.

Aquifer tests in well $\mathrm{J}-13$ resulted in transmissivities between 0.1 and $4.5 \mathrm{~m}^{2} /$ day for the confining beds beneath the Topopah Spring Tuff (Thordarson, 1983, p. 27). The Calico Hills Formation tested in borehole USW SD-7 is often considered a confining bed, and it lies beneath the Topopah Spring Tuff. It is assumed that the same stratigraphic unit was tested in well J-13 and borehole USW SD-7. The transmissivity estimates are similar for these two boreholes,

Table 11. Reservoir-volume estimates for the March and August 1995 aquifer testing in borehole USW SD-7

\begin{tabular}{ccccc}
\hline Testing period & $\begin{array}{c}\text { Initial saturated } \\
\text { thickness } \\
\text { (meters) }\end{array}$ & $\begin{array}{c}\text { Residual drawdown } \\
\text { due to pumping } \\
\text { (meters) }\end{array}$ & $\begin{array}{c}\text { Volume of water } \\
\text { pumped } \\
\text { (liters) }\end{array}$ & $\begin{array}{c}\text { Estimated pre- } \\
\text { pumping reservolr } \\
\text { volume } \\
\text { (liters) }\end{array}$ \\
\hline March & 8.4 & 2.3 & 35,500 & 97,000 \\
August & 7.4 & 2.9 & 46,500 & 86,000 \\
\hline Based on water levels measured at start and end of testing period; long-term recovery and drilling-activity impacts are not \\
included.
\end{tabular}

Table 12. Summary of transmissivity estimates from aquifer tests 4 and 8 in borehole USW SD-7

$[-$, no data $]$

\begin{tabular}{cclc}
\hline Test number & Data analyzed & Method of analysis & $\begin{array}{c}\text { Transmissivity } \\
\text { (meters }{ }^{2} \text { day) }\end{array}$ \\
\hline 4 & Drawdown & Straight-line & 8 \\
& Drawdown & Rorabaugh & 9 \\
8 & Drawdown & Straight-line & 4 \\
& Drawdown & Rorabaugh & 5 \\
Mean & -- & -- & 6 \\
\hline
\end{tabular}


which provides confidence that the analysis on borehole USW SD-7 drawdown data is reasonable.

Transmissivity values obtained from the straight-line and Rorabaugh methods differ by only $1 \mathrm{~m}^{2} /$ day for each test. The agreement between the two methods provides confidence that the transmissivity estimates are realistic and that the methods are appropriate. The straight-line method is based on data obtained prior to the influence of the reservoir boundary, and the Rorabaugh method assumes that there is a nearly instantaneous head drop at the reservoir boundary in response to pumping in the borehole. The contradiction in stating different times (300 minutes versus instantaneously) that the boundary effects are noticeable does not produce significant differences in the transmissivity estimates.

\section{SUMMARY AND CONCLUSIONS}

Aquifer tests were completed in three boreholes in the Yucca Mountain area between March 1995 and January 1996. The single-borehole tests were conducted to obtain estimates of aquifer transmissivity, borehole specific capacity, and reservoir volume of a perched-water body. Several analytical solutions were used in the analysis of the available data.

The highest estimates of specific capacity and transmissivity were in borehole USW WT-10, which was completed in the Topopah Spring Tuff. Mean specific capacity after 5 hours of pumping was $1,100 \mathrm{~m}^{2} /$ day and after 24 hours of pumping was estimated to be $740 \mathrm{~m}^{2} /$ day. Mean transmissivity, based on the analysis of three drawdown tests, was $1,600 \mathrm{~m}^{2} /$ day. Because of the high transmissivity in this borehole, the aquifer did not appear to be significantly stressed during pumping, and only a small portion of the aquifer was actually tested. The maximum discharge rate possible with the pump used was $4.78 \mathrm{~L} / \mathrm{s}$. Additional aquifer testing at discharge rates of 10 to $30 \mathrm{~L} / \mathrm{s}$ are necessary to test a larger portion of the aquifer.

Aquifer testing in borehole UE-25 WT\#12 was dominated by well loss and the associated sensitivity to discharge rate. Drawdown curves had a cyclic nature, which was attributed to relatively minor changes in discharge. An analyzable step-drawdown test was not obtained, so a quantitative assessment of well loss was not possible.
Borehole UE-25 WT\#12 was probably producing water from secondary fractures that could provide only a limited amount of water to the hole. Secondary fractures intersected by the borehole were probably hydraulically connected to a network of primary, or higher transmissivity, fractures that could produce higher volumes of water than was produced from the borehole. Therefore, a significant cone of depression did not appear to be developed around the borehole after extensive pumping.

Mean specific capacity, in borehole UE-25 WT\#12, after 24 hours of pumping was $7 \mathrm{~m}^{2} /$ day. A mean transmissivity of $7 \mathrm{~m}^{2} /$ day was obtained based on analysis of three drawdown tests. Due to boreholestorage effects, the recovery data were not analyzable. The transmissivity estimate is probably a lower limit for the Topopah Spring Tuff. Results from USW WT-10 and other Yucca Mountain wells that tested this unit indicate that transmissivities commonly are two to four orders of magnitude higher.

A perched-water body was hydraulically tested during March and August 1995 in borehole USW SD-7. The water level was approximately $150 \mathrm{~m}$ above the regional water table and near the base of the Calico Hills Formation. A 30-hour aquifer test was conducted at a discharge rate of $0.21 \mathrm{~L} / \mathrm{s}$ after water was initially observed during March 1995 . Following additional coring and deepening of the borehole, a second series of tests was completed in August 1995. A 64.6-hour aquifer test at a discharge rate of $0.16 \mathrm{~L} / \mathrm{s}$ indicated that water was entering the hole from a discrete interval at a borehole depth of about $488 \mathrm{~m}$. A mean specific capacity of $4 \mathrm{~m}^{2} /$ day and a mean transmissivity of $6 \mathrm{~m}^{2} /$ day were obtained from analysis of two drawdown tests. These results are consistent with aquifer testing in the saturated section of the Calico Hills Formation at Yucca Mountain. Accessible reservoir volume was estimated to be about $96,000 \mathrm{~L}$ prior to pumping. Long-term recovery of water levels may indicate that additional perched water, that was not well connected to USW SD-7, may be present in the vicinity of the borehole.

The aquifer tests in boreholes USW WT-10 and UE-25 WT\#12 were the first attempts to obtain transmissivity estimates since the boreholes were completed in August of 1983. Although the aquifer tests were not conducted under ideal equipment or borehole conditions, the information obtained contributes to the understanding the flow system at Yucca Mountain. Borehole USW SD-7 provided the 
opportunity to test a perched-water body and to obtain estimates of transmissivity and reservoir volume. The high degree of variability in transmissivity estimates obtained in these boreholes indicates that Yucca Mountain is highly heterogeneous with respect to transmissivity, and that additional aquifer tests in other boreholes are necessary to quantify the distribution of aquifer transmissivity.

\section{REFERENCES CITED}

American Society for Testing and Materials (ASTM), 1993, Standard test method for determining specific capacity and estimating transmissivity at the control well: American Society for Testing and Materials, Designation D 5472-93, 4 p.

Cooper, H.H., Jr., and Jacob, C.E., 1946, A generalized graphical method for evaluating formation constants and summarizing well-field history: American Geophysical Union Transactions, v. 27, no. 7, p. 526-534.

Craig, R.W., and Robison, J.H., 1984, Geohydrology of rocks penetrated by test well UE-25p \#1, Yucca Mountain area, Nye County, Nevada: U.S. Geological Survey Water-Resources Investigations Report 84-4248, $57 \mathrm{p}$.

Driscoll, F.G., 1986, Groundwater and wells (2d ed.): St. Paul, Minn., Johnson Division, 1089 p.

Earlougher, R.C., 1977, Advances in well test analysis: Monograph series, vol. 5, American Institute of Mining, Metallurgical, and Petroleum Engineers (AIME), Dallas, $264 \mathrm{p}$.

Erickson, J.R., and Waddell, R.K., 1985, ldentification and characterization of hydrologic properties of fractured tuff using hydraulic and tracer tests - Test well USW H-4, Yucca Mountain, Nye County, Nevada: U.S. Geological Survey Water-Resources Investigations Report 85-4066, $30 \mathrm{p}$.

Freeze, R.A., and Cherry, J.A., 1979, Groundwater: Englewood Cliffs, N.J., Prentice-Hall, Inc., $604 \mathrm{p}$.
Kawecki, M.W., 1995, Meaningful interpretation of stepdrawdown tests: Ground Water, v. 33, no. 1, p. 23-32.

Lohman, S.W., 1963, Method for determination of the coefficient of storage from straight-line plots without extrapolation: U.S. Geological Survey Water-Supply Paper 1545-C, p. 33-37.

Lohman, S.W., 1979, Ground-water hydraulics: U.S. Geological Survey Professional Paper 708, 70 p.

Nelson, P.H., Muller, D.C., Schimschal, Ulrich, and Kibler, J.E., 1991, Geophysical logs and core measurements from forty boreholes at Yucca Mountain, Nevada: U.S. Geological Survey Geophysical Investigations Map GP-1001, 64 p.

Plume, R.W., and La Camera, R.J., 1996, Hydrogeology of rocks penetrated by test well JF-3, Jackass Flats, Nye County, Nevada: U.S. Geological Survey WaterResources Investigations Report 95-4245, $21 \mathrm{p}$.

Robison, J.H., Stephens, D.M., Luckey, R.R., and Baldwin, D.A., 1988, Water levels in periodically measured wells in the Yucca Mountain area, Nevada, 1981-1987: U.S. Geological Survey Open-File Report 88-468, 132 p.

Rorabaugh, M.I., 1956, Ground water in northeastern Louisville, Kentucky, with reference to induced infiltration: U.S. Geological Survey Water-Supply Paper 1360-B, p. 101-168.

Schafer, D.C., 1978, Casing storage can affect pumping test data: St. Paul, Minn., Johnson Drillers' Journal, Third Quarter, Johnson Division, UOP Inc.,

Thordarson, William, 1983, Geohydrologic data and test results from well J-13, Nevada Test Site, Nye County, Nevada: U.S. Geological Survey Water-Resources Investigations Report 83-4171, $57 \mathrm{p}$.

Thordarson, William, and Howells, Lewis, 1987, Hydraulic tests and chemical quality of water at well USW VH-1, Crater Flat, Nye County, Nevada: U.S. Geological Survey Water-Resources Investigations Report 86-4359, $19 \mathrm{p}$.

Young, R.A., 1972, Water supply for the nuclear rocket development station at the U.S. Atomic Energy Commission's Nevada Test Site: U.S. Geological Survey Water-Supply Paper 1938, 19 p. 